\title{
Arenicolides A-C, 26-Membered Ring Macrolides from the Marine Actinomycete Salinispora arenicola
}

\author{
Philip G. Williams ${ }^{\dagger} \S$, Eric D. Miller ${ }^{\dagger}$, Ratnakar N. Asolkar, Paul R. Jensen, and William \\ Fenical $^{*}$ \\ Center for Marine Biotechnology and Biomedicine, Scripps Institution of Oceanography, University \\ of California-San Diego, La Jolla, California 92093-0204
}

\begin{abstract}
Chemical evaluation of the saline fermentation broth of several strains of the obligate marine actinomycete Salinispora arenicola has led to the identification of three new macrolide polyketides designated arenicolides A-C(1-3). The planar structures, elucidated via spectroscopic and chemical methods, consist of 26-membered polyunsaturated macrolactones containing repeating vicinal hydroxyl methoxyl moieties. The relative and absolute stereochemistries of 1-3 were assigned by a combination of $J$-based configurational analyses and chemical derivatization.
\end{abstract}

\section{Introduction}

Drugs that trace their heritage to secondary metabolites have more than doubled the average lifespan of human beings. ${ }^{1}$ Microbes represent one of the most prolific sources of these metabolites ${ }^{2}$ however, the efficiency of microbial secondary metabolite discovery must continue to be improved if this resource is to be effectively exploited. ${ }^{3}$ One of the most important decisions that must be made in the search for new microbial metabolites involves the criteria by which individual strains are selected for fermentation and subsequent biological screening. For the past several years, we have been focusing on marine sediment-derived actinomycetes that require seawater for growth. The rational behind this approach is that bacteria adapted to life in the marine environment includes among those adaptations, the production of secondary metabolites not previously observed from well-studied terrestrial taxa. This strategy has led to the discovery of the marine actinomycete genus Salinispora and the potent proteasome inhibitor salinosporamide $\mathrm{A},{ }^{4}$ which is currently in phase I human clinical trials for the treatment of cancer. Detailed LC-MS analyses of Salinispora strains continue to yield new secondary metabolites including the cyclopenta $[a]$ indenes cyanosporasides A and B recently reported from "S. pacifica". 5 Large-scale fermentation of the S. arenicola strain CNR-005 has now led to the isolation and structure elucidation of three new oxygenated macrolides, arenicolides A-C (1-3).

\section{Results}

Actinomycete strain, designated CNR-005, was isolated from a marine sediment sample collected at a depth of $20 \mathrm{~m}$ from the coastal water around the island of Guam as previously described. ${ }^{6}$ Analysis of the extract of an initial small-scale culture by LC-MS and ${ }^{1} \mathrm{H}$ NMR spectrometry suggested the presence of two new classes of compounds. ${ }^{7,8,9}$ Subsequent

\footnotetext{
wfenical@ucsd.edu.

These two authors contributed equally to this work.

\$Present Address: Department of Chemistry, University of Hawaii at Manoa, Honolulu, HI 96822
} 
cultivation of strain CNR-005 in 40 1L Fernbach flasks, followed by extraction with XAD-7 resin and elution with acetone, provided $6 \mathrm{~g}$ of a crude organic extract. The crude extract was subsequently fractionated by $\mathrm{RP}-\mathrm{C}_{18}$ chromatography to yield a fraction (fraction $4,50 \%$ $\mathrm{CH}_{3} \mathrm{CN} / \mathrm{H}_{2} \mathrm{O}$ ) from which compounds $\mathbf{1}-\mathbf{3}$ were subsequently isolated.

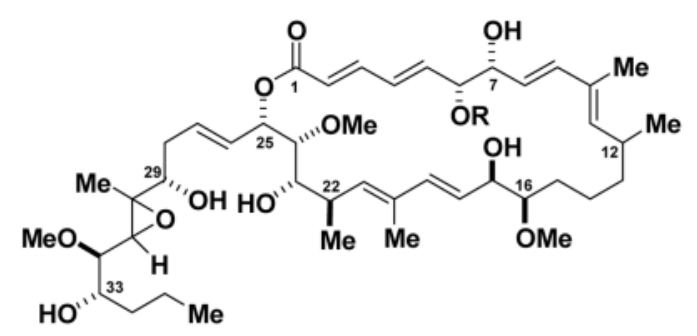

Arenicolide $A$ (1) $R=M e$ Arenicolide $B(2) \mathrm{R}=\mathrm{H}$

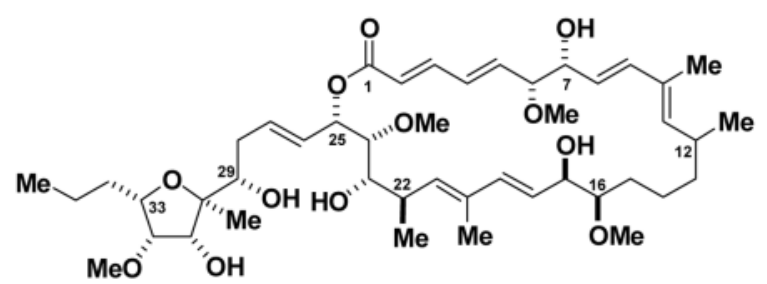

Arenicolide C (3)

Arenicolide A (1) was isolated by RP-HPLC from the $50 \% \mathrm{CH}_{3} \mathrm{CN}$ in water fraction obtained from the $\mathrm{C}_{18}$ flash column extract fractionation $(0.37 \%$ of the crude extract; $0.55 \mathrm{mg} / \mathrm{L})$. Highresolution mass spectral analysis of the optically active amorphous powder $\left([\alpha]_{\mathrm{D}}-72.4 c 0.26\right.$, $\mathrm{MeOH})$ provided a pseudo-molecular ion peak at $827.4916 \mathrm{amu}(0.5 \mathrm{mDa}$ error) that, in conjunction with the ${ }^{13} \mathrm{C}$ NMR data, established the molecular formula of $\mathbf{1}$ as $\mathrm{C}_{45} \mathrm{H}_{72} \mathrm{O}_{12}$. The IR spectrum of $\mathbf{1}$ contained bands consistent with alcohol and ester functional groups (3417 and $1738 \mathrm{~cm}^{-1}$ respectively), while the UV absorptions at 234 and 261 were suggestive of an extended system of conjugation. This supposition was supported by the $15-s p^{2}$ carbon signals visible in the ${ }^{13} \mathrm{C}$ NMR spectrum. In total 45 carbon resonances were observed in the DEPT and ${ }^{13} \mathrm{C}$ NMR spectra, which were ascribed to 4 quaternary, 25 methine, 6 methylene, and 10 methyl carbons. Based on the carbon chemical shifts of these resonances, 1 was composed of 1 ester and 7 double bonds that accounted for 8 of the total 10 degrees of unsaturation implied by the molecular formula. This indicated arenicolide A contained 2 rings. The carbon NMR data also contained a multitude of oxymethine carbon resonances, which in conjunction with the aforementioned data demonstrated the likely polyketide origin of $\mathbf{1}$.

Analysis of the 2D NMR data of arenicolide A (1) (acetone- $d_{6}$ at $500 \mathrm{MHz}$ ) established the six discrete spin systems shown in Figure 1. From these data it became apparent that 1 contained a repeating structural motif of vicinal hydroxyl and methoxyl groups. The spectral overlap caused by this common subunit proved to be problematic in the structure elucidation of $\mathbf{1}$. Nonetheless, the constitution of the largest spin system (A) was defined starting from the ester carbonyl carbon $\mathrm{C}-1$ that, based on $\mathrm{HMBC}$ correlations from $\mathrm{H}-2\left[\delta_{\mathrm{H}-2} 5.96, \delta_{\mathrm{C}-2} 122.7\right]$ and $\mathrm{H}-3\left[\delta_{\mathrm{H}-3} 7.23, \delta_{\mathrm{C}-3} 144.6\right]$, was in conjugation with a trans disubstituted olefin $\left[J_{2,3}=14.9\right.$ $\mathrm{Hz}$. This chromophore was extended based on a COSY correlation from this latter proton signal $\mathrm{H}-3$ to $\mathrm{H}-4$, which belonged to another trans disubstituted olefin $\left[\delta_{\mathrm{H}-4} 6.42, \delta_{\mathrm{C}-4} 132.6\right.$; $\left.\delta_{\mathrm{H}-5} 5.91, \delta_{\mathrm{C}-5} 140.7 ; J_{4,5}=15.4 \mathrm{~Hz}\right]$. HMBC correlations from the $\delta$-proton of this unsaturated system $(\mathrm{H}-5)$ to two oxymethine carbons $\left[\delta_{\mathrm{H}-6} 3.57, \delta_{\mathrm{C}-6} 86.7 ; \delta_{\mathrm{H}-7} 3.96, \delta_{\mathrm{C}-7} 75.8\right]$ established 
the first spin system containing a vicinal hydroxyl methoxyl moiety. While partial structure A could not be extended beyond C-7 with any degree of confidence due to spectral overlap, HMBC NMR correlations at the other end of this unit to the ester carbonyl C-1 established $\mathrm{H}-25\left[\delta_{\mathrm{H}-25} 5.40\right]$ as the acyloxy proton of this functional group. The two carbons adjacent to this methine could be identified by COSY correlations from this proton $(\mathrm{H}-25)$ to the oxygenated methine $\mathrm{H}-24\left[\delta_{\mathrm{H}-24} 3.33\right]$ and to a second-order vinyl proton signal $\mathrm{H}-26\left[\delta_{\mathrm{H}-26}\right.$ 5.82]. Correlations observed in the COSY and HMBC spectra of 1 from the overlapping second order olefinic proton signals (H-26 and H-27) to methylene proton and methine carbon signals established the remaining carbon backbone of fragment $\mathbf{A}$. Partial structure $\mathbf{B}$ was deduced as a $\beta$-substituted diene based on HMBC correlations from the methyl group $\mathrm{H}_{3}-41$ to $\mathrm{sp} 2$ carbon signals for C-19, C-20, and C-21 [ $\left.\delta_{\mathrm{C}-19} 136.9 ; \delta_{\mathrm{C}-20} 133.8 ; \delta_{\mathrm{C}-21} 136.0\right]$. A suite of COSY correlations starting from the proton signal of this latter carbon connected $\mathrm{H}-21$ to the methine proton $\mathrm{H}-22$ and to the methyl doublet $\mathrm{H}_{3}-42$. Interestingly, NMR analysis indicated fragment $\mathbf{C}$ was identical to fragment $\mathbf{B}$, but composed C-8 through C-12.

Substructures $\mathbf{D}$ and $\mathbf{E}$ both contained this repeating vicinal hydroxy methoxy motif $\left[\delta_{\mathrm{C}-32}\right.$ $83.9 / \delta_{\mathrm{C}-33} 72.0$ and $\delta_{\mathrm{C}-16} 85.6 / \delta_{\mathrm{C}-17} 75.7$ respectively] based on analysis of the gDQF-COSY and gHMBC data. One of these two carbon fragments, substructure $\mathbf{D}$, could be expanded through analysis of the HMBC correlations to these two carbons from a methine doublet [ $\left.\delta_{\mathrm{H}-31} 2.85\right]$, which allowed this unit to be connected to one end of a trisubstituted epoxide. Evidence supporting the existence of this three-member ring was the distinctive carbon chemical shifts of C-30 and C-31 [ $\left.\delta_{\mathrm{C}-30} 62.1 ; \delta_{\mathrm{C}-31} 62.7\right]$. The final spin-system, substructure F, was assigned as an $n$-propyl chain based on the NMR data recorded in acetone- $d_{6}$. This was established from HMBC correlations from the methyl triplet $\left(\delta_{\mathrm{H}-36} 0.90, J_{36,35}=7.3 \mathrm{~Hz}\right)$ to two methylene carbons $\mathrm{C}-35$ and $\mathrm{C}-34\left[\delta_{\mathrm{C}-35} 19.5 ; \delta_{\mathrm{C}-34} 36.1\right]$. An inventory of the atoms remaining revealed 2 methylene carbons $\left[\delta_{\mathrm{C}-13} 38.2 ; \delta_{\mathrm{C}-14} 24.2\right]$ and one oxygenated methine $\left[\delta_{\mathrm{C}-23} 76.5\right]$ that still needed to be connected to these partial structures.

Unfortunately, due to overlap of several of the key residues in the proton and carbon NMR spectra, e.g., C-7 and C-17 [ $\left.\delta_{\mathrm{H}-7} 3.96, \delta_{\mathrm{C}-7} 75.8 ; \delta_{\mathrm{H}-17} 3.96, \delta_{\mathrm{C}-17} 75.7\right]$, these partial structures could not be assembled with a high degree of confidence. In the end, it became necessary to acquire the NMR spectra of $\mathbf{1}$ in a different solvent $\left(\mathrm{CDCl}_{3}\right.$, Table 2$)$, in which key proton signals were sufficient dispersed. ${ }^{10}$ In this solvent, it was now possible to link C-7 of unit $\mathbf{A}$ to $\mathrm{C}-8$ of unit $\mathbf{C}$ based on a COSY correlation from $\mathrm{H}-8$ to $\mathrm{H}-7$ and a HMBC correlation from $\mathrm{H}-9$ to $\mathrm{C}-7$. With the position of this center clearly established, C-17 of fragment $\mathbf{E}$ could be joined to $\mathrm{C}-18$ of fragment $\mathbf{B}$ due to similar COSY and HMBC cross peaks, as previously mentioned. Likewise, the conclusive placement of C-7/C-8 suggested fragment $\mathbf{F}$, the propyl chain, was connected to C-33 of unit $\mathbf{D}$ based on an HMBC correlation from $\mathrm{H}-33$ [ $\delta_{\mathrm{H}-33} 3.68$ ] to $\mathrm{C}-34$ and C-35. The other end of substructure $\mathbf{D}$ was attached to unit $\mathbf{A}$ on the basis of $\mathrm{HMBC}$ correlations from $\mathrm{H}-29\left[\delta_{\mathrm{H}-29} 3.39\right]$ to $\mathrm{C}-30\left[\delta_{\mathrm{C}-30} 60.7\right], \mathrm{C}-31\left[\delta_{\mathrm{C}-31} 60.9\right]$ and $\mathrm{C}-44\left[\delta_{\mathrm{C}-44}\right.$ 14.1]. Finally, the one remaining oxymethine carbon $\left[\delta_{\mathrm{H}-23} 3.17, \delta_{\mathrm{C}-23} 75.7\right]$ that could not be connected to any of the fragments based on the NMR data recorded in acetone was used to join fragment $\mathbf{A}$ to $\mathbf{B}$ on the basis of a network of COSY correlations, spanning $\mathrm{H}-24$ to $\mathrm{H}-22$, observed in $\mathrm{CDCl}_{3}$.

What remained were methylene carbons that, on the basis of the structural fragments proposed so far, appeared to connect fragment $\mathbf{E}$ to $\mathbf{C}$ to form a 26-membered macrocyclic ring. The NMR evidence for the placement of these two carbons within the macrocycle was, however, equivocal and there was some uncertainty about the assignment of $\mathrm{H}_{2}-34$ and $\mathrm{H}_{2}-35$ to the side chain. This left the possibility that 1 contained either a 26- or 27-membered macrocycle. To unambiguously resolve this issue would require degradation of $\mathbf{1}$ in a manner that would discriminate between the two ring sizes. Therefore, a small sample of $\mathbf{1}$ was degraded by ozonolysis with a reductive workup and the resulting complex mixture analyzed by LC-MS 
and ${ }^{1} \mathrm{H}$ NMR spectrometry. While $\mathbf{1}$ was completely consumed, this experiment yielded no clear evidence of fragments consistent with any of the proposed ring structures. A search of the literature for alternative strategies revealed an elegant report using olefin cross-metathesis to degrade a simple polyacetylenic oxylipid. ${ }^{11}$ Arenicolide A (1) represented a much more daunting problem as cross metathesis with this complex polyene could potentially yield a myriad of reaction products. Given the electrophilic nature of the metathesis initiators and their sensitivity to steric bulk, the predominant metathesis product should result from cleavage of the isolated $\Delta_{26}$ olefin as compared to the lower energy dienes. Arenicolide A (1) was stirred with the commercially available second-generation Grubb's catalyst in DCM under 5 atmospheres of ethylene (Scheme 1). Despite the slow rate of cross metathesis, analysis of the reaction mixture by LC-MS indicated the presence of a small amount of the 27-carbon backbone macrocycle $\left(\mathbf{5}, \mathrm{C}-1\right.$ through C-27). ${ }^{12}$ Concurrent to these degradation experiments, the structure of arenicolide $\mathrm{C}$ ( $\mathbf{3}$ ) was established, and unlike $\mathbf{1}$, the carbon backbone of $\mathbf{3}$ was unambiguously assigned by interpretation of NMR spectroscopic data. On the basis of the information gained from the structure of $\mathbf{3}$, arenicolide A was a 26-membered macrolide and therefore no further characterization of the metathesis reaction products was undertaken.

Arenicolide B (2) eluted from the $\mathrm{C}_{18}$ HPLC column prior to $1\left(1 t_{\mathrm{R}}=69 \mathrm{~min} ; \mathbf{2} t_{\mathrm{R}}=55 \mathrm{~min}\right)$ and was assigned the molecular formula $\mathrm{C}_{44} \mathrm{H}_{70} \mathrm{O}_{12}$ (HRESI-TOFMS [M+Na] ${ }^{+}$ion at $\mathrm{m} / \mathrm{z}$ 813.4751), indicating 2 was 14 amu smaller than $\mathbf{1}$. Comparison of the proton and carbon NMR spectra of $\mathbf{1}$ and $\mathbf{2}$ (Table 3 for ${ }^{1} \mathrm{H}$ and ${ }^{13} \mathrm{C}$; See Table $\mathrm{S} 1$ for complete NMR data) established that 2 was the C-6 O-desmethyl isomer of arenicolide A, as indicated by loss of the corresponding methoxy singlet and the upfield shift of C-6 [ $\left.\delta_{C-6} 75.7\right]$. Analysis of the $2 \mathrm{D}$ NMR data conclusively established the gross structure as depicted for 2.

Arenicolide C (3), isolated from the same fraction that contained $\mathbf{1}$ and $\mathbf{2}$, was identified as a congener of 1 given the similarity of its spectral data. The high-resolution mass spectrum of $\mathbf{1}$ suggested a molecular formula of $\mathrm{C}_{45} \mathrm{H}_{72} \mathrm{O}_{12}$, which confirmed that $\mathbf{1}$ and $\mathbf{3}$ were isomeric. Several differences in the resonances for the side chain $(\mathrm{H}-29-\mathrm{H}-35)$ were visible in the ${ }^{1} \mathrm{H}$ and ${ }^{13} \mathrm{C}$ NMR spectra. In particular, the large downfield shifts of C-30 and C-31 $\left(\delta_{\mathrm{C}-30} 82.8\right.$, $\left.\delta_{\mathrm{C}-31} 81.5\right)$ indicated that the oxirane ring was not a structural feature of 3 . Analysis of the $2 \mathrm{D}$ NMR data provided evidence for a substituted tetrahydrofuran ring formed from C-30 through C-33. Specifically, a clear HMBC correlation was observed between H-33 and C-30, as well as a NOE correlation between $\mathrm{H}-34$ and $\mathrm{H}-45$, indicative of the proposed ring structure assigned for 3 .

The relative stereochemistry of each of the seven olefins in $\mathbf{1}$ was assigned as follows. The configurations of the two-trisubstituted olefins $\left(\Delta_{10}, \Delta_{20}\right)$ were deduced as $E$ from analysis of the ROESY spectral data recorded in acetone- $d_{6}$. In both cases, ROE correlations were observed from the methyl proton signals to the neighboring $s p^{3}$ methine proton signals; i.e., for the $\Delta_{10}$ and $\Delta_{20}$ double bonds, cross-peaks were observed from $\mathrm{H}_{3}-38$ to $\mathrm{H}-12$ and from $\mathrm{H}_{3}-41$ to $\mathrm{H}-22$, respectively. The $E$ configurations of four of the five disubstituted double bonds were assigned based on their characteristic ${ }^{3} J_{\mathrm{H}, \mathrm{H}}$ values observed in acetone- $d_{6}\left(J_{\Delta 2}=14.9\right.$ $\mathrm{Hz}, J_{\Delta 4}=15.4 \mathrm{~Hz}, J_{\Delta 8}=15.6 \mathrm{~Hz}$ and $\left.J_{\Delta 18}=16.1 \mathrm{~Hz}\right)$. The configuration of the remaining disubstituted double bond $\left(\Delta_{26}\right)$ could not be established at this time from the NMR data of 1-3, recorded in a variety of solvents, ${ }^{13}$ due to apparent second-order coupling between H-26 and $\mathrm{H}-27$. This configuration was determined by analyzing the corresponding ${ }^{3} J_{\mathrm{H}, \mathrm{H}}$ values in the derivative 6.

The 14 chiral centers in 1 could be arranged into six discrete units. The relative configurations of five of these units were determined by a combination of $J$-based configurational analyses and chemical derivatization. The sixth unit was comprised of a secondary methyl group, the stereochemistry of which was not deduced herein. Initial investigations indicated that two sets 
of the vicinal stereogenic centers had proton-proton coupling constants whose magnitude was defined as "large" according to Murata et al., ${ }^{14}$ thus allowing the configuration of these centers to be determined by ROESY or NOESY correlations. A threo configuration could be assigned between the vicinal stereocenters C- 6 and C-7 based on the magnitude of the ${ }^{3} J_{\mathrm{H}-6, \mathrm{H}-7}$ constant $\left(8.5 \mathrm{~Hz} ; \mathrm{CDCl}_{3}\right)$ and the NOE observed between $\mathrm{H}-5$ and $\mathrm{H}-8$ (Figure 2). Likewise, a threo configuration was assigned between stereocenters C-22 and C-23 based on a proton-proton coupling constant of $10.0 \mathrm{~Hz}$ between their respective protons, and an observed NOE between H-21 and H-24 that established a gauche orientation for these two substituents (Figure 2). The stereochemical relationship between $\mathrm{H}-22 / \mathrm{H}-23$ could not be extended to the adjacent stereocenters (C-24 \& C-25) using a $J$-based configuration analysis approach due to an insufficient signal-noise ratio for these resonances in a G-BIRD $D_{R}-H S Q M B C$ experiment. 15 $J$-based configuration analysis was used to establish the threo configuration between the vicinal centers $\mathrm{C}-16$ and $\mathrm{C}-17$. The intermediate magnitude of the homonuclear coupling constant $\left({ }^{3} J_{\mathrm{H}-16 / \mathrm{H}-17}=6.3 \mathrm{~Hz}\right)$ for this dioxygenated unit suggested a mixture of rotamers at these two vicinal stereocenters. Three-bond proton-carbon coupling constants measured between H-16/ C-18 and H-17/C-15 were also of an intermediate magnitude. Taken together these data are most consistent with an interconverting mixture of the anti $(-)$ - and (+)-gauche rotamers as shown in Figure 2.

To relate the centers at C-24 and C-25 to C-22 and C-23 required methanolysis of 1 and conversion of the resulting diol to the acetonide derivative (6) by reaction with PPTS (pyridinium toluenesulfonate) and dimethoxypropane. Analysis of the NMR spectroscopic data for 6, recorded in MeOH- $d_{4}$ (See Table S4 in supporting information), established the 1,3dioxane ring existed in a twist-boat conformation as defined by the carbon chemical shifts of the ketal carbon $\left(\delta_{\mathrm{C}-49} 102.9\right)$ and the nearly identical chemical shifts of the gem-dimethyl carbons $\left(\delta_{\mathrm{C}-47} 25.2\right.$ and $\left.\delta_{\mathrm{C}-48} 24.8\right) .{ }^{16}$ Taken together these data established the anti configuration of H-23 and H-25 in compound $\mathbf{6}$. The configuration of these centers relative to $\mathrm{H}-24$ was deduced by analysis of the proton-proton coupling constants $\left(J_{23,24}=2.4 \mathrm{~Hz}\right.$; $J_{24,25}=5.8 \mathrm{~Hz}$ ) in the 1,3-dioxane ring and comparison with a model compound (7), present in the literature (Figure 3). ${ }^{17}$ These data established the anti and syn stereochemical relationships in 6 between $\mathrm{H}-24 / \mathrm{H}-25$ and $\mathrm{H}-23 / \mathrm{H}-24$, respectively.

In the side chain (C-26 to C-36), the configuration of the epoxide was assigned based upon a ROESY correlation observed in acetone- $d_{6} .18$ A cross peak between $\mathrm{H}_{3}-44$ and $\mathrm{H}-32$ established their likely cis relationship, thus implying the trans configuration of the epoxide (C-30/C-31). Unfortunately, relating the configuration of the epoxide to the adjacent centers (C-29 or C-32) was not possible by $J$-based configuration analysis due to a combination of poor signal-to-noise in the G-BIRD $\mathrm{R}_{\mathrm{H}}$-HSQMBC spectrum and the lack of appropriate comparison data from models systems. 19

Based on the structural similarity, $\mathbf{1}$ is likely either a biosynthetic precursor to $\mathbf{3}$ or they share a late stage biosynthetic intermediate. Therefore, the relative and absolute configurations deduced for the stereocenters in $\mathbf{1}$ are likely the same in $\mathbf{3}$ and vice versa. The near superimposable negative cotton effect observed in the CD spectra of 1-3 (Figure 4) is evidence to support the hypothesis that the absolute stereochemistry of $\mathbf{1 - 3}$ is the same within the macrocycle and likely also within the side chain. Given the strong structural similarity between $\mathbf{1}$ and 3, the stereochemical relationship between C-32 and C-33 in $\mathbf{1}$ could be inferred from the corresponding centers in arenicolide C (3), as shown in Figure 5. Specifically, NOE correlations observed in DPFGSE-1D NOE experiments on $\mathbf{3}$, in $\mathrm{CDCl}_{3}$ and acetone- $d_{6}$, between $\mathrm{H}-33, \mathrm{H}-32$ and $\mathrm{H}-31$ in the side chain established the relative configuration of these centers in 3. Extrapolating this to the linear compounds $\mathbf{1}$ and $\mathbf{2}$, by opening up the THF ring, suggests the stereochemistry depicted in Figure 5 for C-32 and C-33 in $\mathbf{1}$. 
Two stereocenters in the side chain of $\mathbf{1}$, at C-30 and C-31, cannot be assigned based on this analysis because multiple mechanisms exist for the conversion of $\mathbf{1}$ to $\mathbf{3}$ involving either inversion or retention of configuration at those centers. For example, analogous to the CaneCelmer-Westley model ${ }^{20}$ for the biosynthesis of monensin, substitution of 33-OH at C-30 by an $\mathrm{S}_{\mathrm{N}} 2$ mechanism inverts the stereochemistry at this latter center if $\mathbf{1}$ is directly converted to 3. This corresponds to a 5-endo-tet cyclization, which is disfavored according to Baldwin's rules, ${ }^{21}$ but not without precedent as electron donating groups can stabilize a "disfavored" transition state 22 and Lewis Acids can induce disfavored cyclizations. ${ }^{23}$ The same disfavored cyclization can be accomplished with a catalytic antibody, which demonstrates the biosynthetic feasibility of the proposal. ${ }^{24}$ Disfavored cyclizations are also postulated in the biosynthesis of marine polyether brevetoxin, which is believed to involve a series of nine disfavored endo-tet cyclizations. ${ }^{25}$ This all serves to reinforce the likelihood of a $\mathrm{S}_{\mathrm{N}} 2$ conversion of 1 to 2 involving an inversion of stereochemistry at $\mathrm{C}-30,26$ but while cyclizations of epoxides clearly have the most biosynthetic precedent, other mechanisms exist. Despite always being present in the crude extract, $\mathbf{3}$ may still be an artifact of a non-enzymatic transformation. In this case, a mechanism involving an initial epoxide migration through a Payne rearrangement ${ }^{27}$ and subsequent formation of the tetrahydrofuran ring by a favored 5-exo-tet $\mathrm{S}_{\mathrm{N}} 2$ cyclization would result in retention of configuration at $\mathrm{C}-30$ due to double inversion at this center. Likewise, a mechanism involving a $\mathrm{S}_{\mathrm{N}} 2$ nucleophilic opening of the epoxide at $\mathrm{C}-31$ by water, subsequent loss of the resulting tertiary alcohol at C-30 to give a carbocation that is quenched intramolecularly by the $\mathrm{C}-33$ hydroxyl group has the potential to invert both stereocenters. ${ }^{28}$ It is this latter possible mechanism that prevents relating the stereochemistry of C-30/31 between 3 and $\mathbf{1}$. Thus, the relative configuration of the epoxide in $\mathbf{1}$ with respect to the adjacent centers (C-29 \& C-32) remains unassigned.

The evidence presented thus far established the relative configuration of five of the six isolated stereochemical units, which could not be directly related to each other through any obvious means (Figure 6). This necessitated determining the absolute stereochemistry of each of these units. ${ }^{29}$ Several strategies were considered involving complete degradation of $\mathbf{1}$ via either ozonolysis or cross-metathesis. In general, these approaches eventually required either NMR analysis of the degradation products using chiral auxiliaries or necessitated the synthesis of a significant portion of $\mathbf{1}$ in order to generate standards for comparative purposes 30 by GC- or LC-MS or circular dichroism. 31,32 In the end, our inability to conclusively identify fragments from the small scale ozonolysis of $1^{33}$ (vide supra) weighed heavily on our decision to explore approaches that did not involve substantial degradation of $1.34,35$ Given that four out of five of these stereochemical units contained a secondary alcohol, a strategy for determining the absolute stereochemistry of intact arenicolide A (1) using the Mosher NMR spectroscopic method was devised. Since approaches to generate partial per-MTPA derivatives involving protection of the individual alcohols and subsequent derivatization with MTPA were precluded by sample size and the inherent reactivity of $\mathbf{1}$, efforts were focused on preparing the fully acylated, penta-MTPA, derivative. Recent studies have established that MTPA is inferior to $\alpha$-methoxyphenylacetic or 9-anthrylmethoxyacetic acid because of the smaller differences between the ${ }^{1} \mathrm{H}$ NMR chemical shifts in the MTPA derivatives. These smaller differences have been proposed to arise from the comparatively more complex conformational ratios inherent to MTPA. ${ }^{36}$ In the case of $\mathbf{1}$, this attribute was deemed desirable, as it should minimize the undesired cumulative shielding effects due to distal chiral auxiliaries. Therefore, treatment of 1 in separate experiments, with $(R)$ - and $(S)$ - $\alpha$-methoxy- $\alpha$-(trifluoromethyl)phenylacetyl chloride ( $R$ - and $S$-MTPA-Cl) initially yielded a complex mixture of Mosher derivatives which eventually coalesce into the penta-(S)- and penta- $(R)$-MTPA derivatives of $\mathbf{1}$ ( $S$ - and $R-\mathbf{8}$ ), respectively. It should be noted that the rate of formation of $R-\mathbf{8}$ was significantly slower than the corresponding $S$-derivative with the former requiring twice as long to obtain an adequate amount of material for NMR analysis. Despite the prolonged reaction time we observed no appreciable amount of elimination ${ }^{37}$ at the allylic alcohols C-7 and C-17. Assuming the 
conformation of the acetylated derivative at these centers is analogous to 1,38 elimination at these centers would require a sterically unfavorable syn-rather than the favored anti-periplanar elimination owing to a gauche orientation between the acyloxy bond and the adjacent methine proton.

Analysis of ${ }^{1} \mathrm{H}$ NMR chemical shift differences $\left(\Delta \delta_{S-R}\right)$ yielded the values shown in Figure 7. As expected, the $\Delta \delta_{S-R}$ values on each side of the respective derivatized chiral centers were complicated presumably due to shielding effects arising from MTPA units not directly bound to the carbon of interest. Nonetheless, consistent $\Delta \delta_{S-R}$ values for the protons $\alpha$ and $\beta$ to the derivatized centers suggest the absolute configuration for 1 depicted in Figure 7 (for complete assignments see Supplemental S29). It should be noted however that the absolute stereochemistry of C-12, C-30 and C-31 in $\mathbf{1}$ could not be determined via the experiments described. Based on biosynthetic considerations, and the similarity of the CD spectra, the same absolute configuration is suggested for $\mathbf{2}$ and $\mathbf{3}$.

Although the Mosher method was originally developed to determine the absolute configuration of monoalcohols, it has been widely applied to polyols. ${ }^{39}$ Recently, Riguera et al. have sought to rigorously validate this approach for the configurational assignment of acyclic 1,2-, 1,3-, 1,4-, and 1,5-diols by examining the combined anisotropy effects of two phenylacetic acid derivatives. ${ }^{40}$ In general, it appears that the combined chemical shift differences of the acyloxy protons are indicative of the relative and absolute stereochemistry. The configurations proposed from the Mosher analysis of C-29 and C-33 in the side chain are consistent with the trends noted by Riguera for acyclic systems (Figure 8 ). Specifically, the positive $\Delta \delta_{S-R}$ values for C-29 through C-33 are distinctive of the absolute stereochemistry depicted. While this work begins to address the potential problems raised by Mosher analysis of a complex polyol, a number of crucial factors, including the different conformational preference of the macrocycle as compared to the acyclic diols and exactly how to parse $\mathbf{1}$ into diol units, complicate the application of Riguera's predictive models for C-7, C-17, and C-23. However, to the best of our knowledge, in the last 10 years there are no clear examples where the analysis of a polyMTPA derivative was later conclusively proven wrong by synthesis because of a failure of the Mosher method to account for the combined anisotropy. Far more common are errors relating the stereochemistry of that secondary alcohol to the other stereogenic centers in the molecule, which are responsible for the needed structure revision. ${ }^{41}$ The problem arises because although examples of molecules whose stereochemistry was determined by multiple Mosher's analysis are common, cases in which those molecules were then synthesized and the stereochemistry corroborated or corrected are quite rare. More data is clearly needed in this area to truly understand the limitation of the technique. Therefore, the absolute configuration of these secondary alcohols derivatized with the Mosher chiral auxiliary is suggested based on the historically more precedented analysis of the $\Delta \delta_{S-R}$ values directly adjacent to that chiral center.

Finally, while the role of ring-closing metathesis $(\mathrm{RCM})$ and ring-opening metathesis polymerization (ROMP) has been cemented in organic synthesis, the area of olefin crossmetathesis has been slower to develop. ${ }^{42,43}$ This disparity was in part due to the statistical yields of products observed with simple olefins. Recently developed guidelines now allow the outcome of cross metathesis reactions to be predicted based on the relative rates of homodimerization of the alkenes using the commercially available ruthenium- and molybdenum-based initiators. ${ }^{44}$ For natural product chemists, olefin cross metathesis becomes an attractive alternative to ozonolysis and periodate oxidation of alkenes due to its wide functional group tolerance and comparatively mild reaction condtions. As importantly, we demonstrate here the utility of olefin cross metathesis for the degradation of a single alkene within a polyunsaturated macrolide for the purpose of gross structure determination. ${ }^{45}$ Thus, using the predictive guidelines for cross metathesis it is now possible to fine tune the 
regioselectivity to utilize fully this powerful transformation in degradation studies of complex natural products.

Given the impressive bioactivity that is often associated with macrolides, Arenicolide A was evaluated in all of the biological assays available to us. Arenicolide A exhibited moderate cytotoxicity toward the human colon adenocarcinoma cell line HCT-116 $\left(\mathrm{IC}_{50}=30 \mu \mathrm{g} / \mathrm{mL}\right.$ ) and the cell lines in the National Cancer Institute's 3-cell line screen. However, due to its moderate activity further testing in the 60-cell line screen was deemed unwarranted by the NCI. Arenicolide A was also inactive an in-house antimicrobial assay using methicillin-resistant Staphylococcus aureus (MRSA) and vancomycin-resistant Enterococcus faecium (VREF).

\section{Experimental Section}

\section{Fermentation}

Actinomycete strain CNR-005, identified as $S$. arenicola by $16 \mathrm{~S}$ rDNA sequence methods, was isolated from a sediment sample collected at a depth of approximately $30 \mathrm{~m}$ in January 2002 in Guam. The producing organism was cultured in $40 \times 1 \mathrm{~L}$ Fernbach flasks containing A1BFe media (10 g of starch, $4 \mathrm{~g}$ of yeast extract, $2 \mathrm{~g}$ of peptone, $5 \mathrm{~mL}$ of $\mathrm{Fe}_{2}\left(\mathrm{SO}_{4}\right)_{3} \cdot 4 \mathrm{H}_{2} \mathrm{O}$ at $8 \mathrm{~g} / \mathrm{L}, 5 \mathrm{~mL}$ of $\mathrm{KBr}$ at $20 \mathrm{~g} / \mathrm{L}, 1$ liter of seawater) for 7 days at $25-27^{\circ} \mathrm{C}$ on a shaker at 230 $\mathrm{rpm}$. The fermentation broth was then extracted by the addition of $20 \mathrm{~g} / \mathrm{L}$ of XAD-7 resin, which was subsequently collected by filtration and extracted with acetone.

\section{Isolation}

The organic residue $(6 \mathrm{~g})$ from the resin was fractionated by a $\mathrm{C}_{18}$ flash column eluting with increasing amounts of $\mathrm{CH}_{3} \mathrm{CN}$ in water $(2 \times 25 \%, 4 \times 50 \% 4 \times 75 \%, 1 \times 100 \%)$. The fourth fraction that eluted with $50 \% \mathrm{CH}_{3} \mathrm{CN}(380 \mathrm{mg})$ was separated by RP-HPLC $\left[\mathrm{C}_{18}, 25 \times 300\right.$ $\mathrm{mm}$, flow rate $10 \mathrm{~mL} / \mathrm{min}$, detection at $210 \mathrm{~nm}, 20 \%$ for $10 \mathrm{~min}$ then a linear gradient up to $40 \% \mathrm{CH}_{3} \mathrm{CN}$ over $40 \mathrm{~min}$ then 30 more min at $40 \%$ before a linear gradient of $40-100 \%$ over then next $40 \mathrm{~min}$ ] to afford arenicolide $\mathrm{A}\left(\mathbf{1}, t_{\mathrm{R}}=69 \mathrm{~min}\right)$, arenicolide $\mathrm{B}\left(\mathbf{2}, t_{\mathrm{R}}=55 \mathrm{~min}\right)$, and arenicolide $\mathrm{C}\left(\mathbf{3}, t_{\mathrm{R}}=78 \mathrm{~min}\right)$.

Arenicolide A (1), $22 \mathrm{mg}, 0.37 \%$ yield from the crude extract), amorphous powder; $[\alpha]_{\mathrm{D}}-72.4$ (c $0.26, \mathrm{MeOH}) ; \mathrm{UV}(\mathrm{MeOH}) \lambda_{\max }(\log \varepsilon) 234$ (4.6), 261 (4.6) nm; CD (MeOH) $\lambda_{\max }(\Delta \varepsilon)$ 229 (+23.4), $253(-27.0) \mathrm{nm} ; \mathrm{IR}(\mathrm{NaCl}) v_{\max } 3417,1738,1714,1644,1373,1246,1102,1077$ $\mathrm{cm}^{-1}$; See Tables 1 and 2 for tabulated spectral data; ESIMS $\mathrm{m} / z, 827(\mathrm{M}+\mathrm{Na})^{+}$; HRESI-FTMS $m / z 827.4916$ [calcd for $\mathrm{C}_{45} \mathrm{H}_{72} \mathrm{O}_{12} \mathrm{Na}^{+}, 827.4921$ ].

Arenicolide B (2), $2.4 \mathrm{mg}, 0.040 \%$ yield), amorphous powder; $[\alpha]_{\mathrm{D}}-83.9(c \mathrm{c} 0.185, \mathrm{MeOH})$; $\mathrm{UV}(\mathrm{MeOH}) \lambda_{\max }(\log \varepsilon) 234$ (4.5), $260(4.1) \mathrm{nm} ; \mathrm{CD}(\mathrm{MeOH}) \lambda_{\max }(\Delta \varepsilon) 226(+25.6), 256$ $(-26.9) \mathrm{nm}$; IR (NaCl) $v_{\max } 3383,1696,1647,1459,1082,755 \mathrm{~cm}^{-1}$; See Table S1 in supporting information for tabulated spectral data; ESIMS $\mathrm{m} / z 813(\mathrm{M}+\mathrm{Na})^{+}$; HRESI-TOFMS $\mathrm{m} / \mathrm{z} 813.4751$ [calcd for $\mathrm{C}_{44} \mathrm{H}_{70} \mathrm{O}_{12} \mathrm{Na}^{+}$, 813.4759].

Arenicolide C (3), $1.1 \mathrm{mg}, 0.018 \%$ yield), amorphous powder; $[\alpha]_{\mathrm{D}}-92.2$ ( 0 0.1, MeOH); UV $(\mathrm{MeOH}) \lambda_{\max }(\log \varepsilon) 234$ (4.6), $261(4.6) \mathrm{nm} ; \mathrm{CD}(\mathrm{MeOH}) \lambda_{\max }(\Delta \varepsilon) 228(+33.7), 256(-33.7)$ $\mathrm{nm}$; IR (NaCl) $v_{\max } 3417,1738,1714,1644,1373,1246,1102,1077 \mathrm{~cm}^{-1}$; See Table S2 and $\mathrm{S} 3$ in supporting information for tabulated spectral data; ESIMS $\mathrm{m} / \mathrm{z} 827(\mathrm{M}+\mathrm{Na})^{+}$; HRESITOFMS $m / z 827.4908$ [calcd for $\mathrm{C}_{45} \mathrm{H}_{72} \mathrm{O}_{12} \mathrm{Na}^{+}, 827.4921$ ].

\section{Olefin Cross-Metathesis Reaction of 1}

To $2.3 \mathrm{mg}$ of 1 dissolved in $1.0 \mathrm{~mL}$ of DCM was added $1.9 \mathrm{mg}$ of the commercially available second-generation Grubbs catalyst in $0.75 \mathrm{~mL}$ of DCM. The reaction was purged for $10 \mathrm{~min}$ 
then refluxed overnight under ca. 5 atms of ethylene. The reaction was examined by LCMS using RP-HPLC [ $\mathrm{C}_{18}, 10 \times 250 \mathrm{~mm}$, flow rate $0.7 \mathrm{~mL} / \mathrm{min}$, detection by UV210, UV254, using a linear gradient of $10-100 \% \mathrm{CH}_{3} \mathrm{CN}$ over $\left.30 \mathrm{~min}\right]$.

\section{Methanolysis of 1}

To $2.7 \mathrm{mg}$ of arenicolide A (1) was added a suspension of $27 \mathrm{mg}$ of $\mathrm{NaOMe}$ in $1 \mathrm{~mL}$ of anhydrous methanol (distilled from $\mathrm{CaH}_{2}$ ). The solution was stirred at room temp for $2 \mathrm{~h}$ under an argon atmosphere until TLC analysis (Si TLC, 10:1 DCM:MeOH $\mathrm{R}_{f} \mathbf{1}=0.40, \mathrm{R}_{f}$ methanolysis product $=0.36$ ) indicated the conversion was complete. The reaction was quenched with $0.9 \mathrm{~mL}$ of $0.6 \mathrm{~N} \mathrm{HCl}$, diluted with $\mathrm{H}_{2} \mathrm{O}$ and then extracted with EtOAc three times. The organic extracts were combined and dried over $\mathrm{MgSO}_{4}$ and the solvent removed in vacuo. The residue was resuspended in $\mathrm{MeOH}$, filtered and separated by RP-HPLC [Luna $\mathrm{C}_{18}, 10 \times 250 \mathrm{~mm}$, flow rate $3 \mathrm{~mL} / \mathrm{min}$, detection at $254 \mathrm{~nm}, 50 \% \mathrm{CH}_{3} \mathrm{CN}$ for $5 \mathrm{~min}$ then a linear gradient up to $80 \%$ over $40 \mathrm{~min}$ ] to afford the desired product $\left(2.6 \mathrm{mg}, 93 \%\right.$ yield, $\mathrm{t}_{R}=$ $15 \mathrm{~min})$.

\section{Acetonide Formation (6)}

The methanolysis product $(2.6 \mathrm{mg})$ was dissolved in dry acetone $(0.8 \mathrm{~mL})$ and $0.8 \mathrm{~mL}$ of dimethoxypropane. Pyridinium toluenesulfonate was added ( 1 crystal) and the reaction was stirred under an atmosphere of nitrogen. The progress of the reaction was monitored by silica TLC [ $10 \% \mathrm{MeOH}$ in DCM, $\mathrm{R}_{f}$ methanolysis product $=0.24$ and $\mathrm{R}_{f} \mathbf{6}=0.28$ ] and LC-MS [Luna $\mathrm{C}_{18}$, flow rate $0.7 \mathrm{~mL} / \mathrm{min}$, detection at 210 and $254 \mathrm{~nm}$, a linear gradient of 50 to $100 \%$ $\mathrm{CH}_{3} \mathrm{CN}$ over $10 \mathrm{~min}, t_{\mathrm{R}}$ methanolysis product $\left.=5.04 \mathrm{~min}, t_{\mathrm{R}} \mathbf{6}=8.60 \mathrm{~min}\right]$. After $4.5 \mathrm{~h}$ the reaction was terminated even though starting material remained because it appeared that the product $\left(\mathrm{m} / \mathrm{z} 899[\mathrm{M}+\mathrm{Na}]^{+}\right)$was being converted to other compounds. The solvent was removed in vacuo, the sample was dissolved in $\mathrm{MeOH}$ and purified by RP-HPLC $\left[\mathrm{C}_{18}, 250 \times\right.$ $10 \mathrm{~mm}$, flow rate $2.5 \mathrm{~mL} / \mathrm{min}$, detection at $210 \mathrm{~nm}$ and $\mathrm{ELSD}, 60 \% \mathrm{CH}_{3} \mathrm{CN}$ for $2 \mathrm{~min}$ then a linear gradient up to $100 \%$ over the next $28 \mathrm{~min}$ ]. The retention time of the starting material was $9.9 \mathrm{~min}$ and the retention time of the product 6 was $23 \mathrm{~min}(1.1 \mathrm{mg}, 40 \%$ yield).

\section{Arenicolide A Methanolysis Product $(2.6 \mathrm{mg})$}

amorphous powder; $[\alpha]_{\mathrm{D}}+8.0($ c $0.2, \mathrm{MeOH}) ; \mathrm{UV}(\mathrm{MeOH}) \lambda_{\max }(\log \varepsilon) 234$ (4.1), 262 (3.7) $\mathrm{nm}$; IR (NaCl) $v_{\max } 3399,1713,1655,1451,1254,1123,763 \mathrm{~cm}^{-1}$; ESIMS m/z $859(\mathrm{M}$ $+\mathrm{Na})^{+}$; HRESITOFMS $m / z 859.5175$ [calcd for $\mathrm{C}_{46} \mathrm{H}_{76} \mathrm{O}_{13} \mathrm{Na}^{+}$, 859.5178].

\section{Arenicolide A Methanolysis Acetonide (6, 1.1 mg)}

amorphous powder; $[\alpha]_{\mathrm{D}}-9.7(c 0.185, \mathrm{MeOH}) ; \mathrm{UV}(\mathrm{MeOH}) \lambda_{\max }(\log \varepsilon) 202$ (3.7), 233 (3.8), $260(3.5) \mathrm{nm}$; IR ( NaCl) $v_{\max } 3397,1714,1667,1464 \mathrm{~cm}^{-1}$; See Table S4 in Supporting Information for tabulated spectral data; ESIMS $\mathrm{m} / \mathrm{z} 899(\mathrm{M}+\mathrm{Na})^{+}$; HRESITOFMS $\mathrm{m} / \mathrm{z}$ 899.5493 [calcd for $\mathrm{C}_{49} \mathrm{H}_{80} \mathrm{O}_{13} \mathrm{Na}^{+}$, 899.5491].

\section{Preparation of MTPA derivatives}

The Mosher derivatives were prepared following the general procedure outlined by Kwon $e t$ al Identical conditions were used to form the penta- $(R)$ - and penta-(S)-MTPA derivatives and are as follows: To $4.0 \mathrm{mg}$ of arenicolide A was added $1.5 \mathrm{~mL}$ of anhydrous DCM under an atmosphere of argon at room temperature. Following a $30 \mathrm{~min}$ incubation period with vigorous stirring, $6 \mu \mathrm{L}$ of triethylamine was added followed $5 \mathrm{~min}$ later by the addition of 10 crystals of dimethylaminopyridine. The reaction components were stirred for $60 \mathrm{~min}$ then $120 \mu \mathrm{g}$ of $(R)$ or $(S)$-MTPA-Cl was added. The reaction was incubated for another $60 \mathrm{~min}$ at the end of which $750 \mu \mathrm{L} \mathrm{C}_{5} \mathrm{H}_{5} \mathrm{~N}$ was added. Derivatization was monitored at various time points (12, 36 and 48 hours) by LC-MS [Luna $\mathrm{C}_{18}, 4.6 \times 100 \mathrm{~mm}$, flow rate $0.7 \mathrm{~mL} / \mathrm{min}$, PDA detection; $50 \%$ 
$\mathrm{CH}_{3} \mathrm{CN}$ in $\mathrm{H}_{2} \mathrm{O}$ for 15 min then a linear gradient to $100 \% \mathrm{CH}_{3} \mathrm{CN}$ over 10 min then eluting with $100 \% \mathrm{CH}_{3} \mathrm{CN}$ for an additional $25 \mathrm{~min}$ ]. Tetra- and penta-derivatives were distinguished by characteristic LRESIMS values of $[\mathrm{M}+\mathrm{Na}]^{+} \mathrm{m} / z 1691.4$ and $[\mathrm{M}+\mathrm{Na}]^{+} \mathrm{m} / z 1907.4$ respectively. Derivatization of arenicolide A with $(R)$-MTPA-Cl proceeded for 48 hours at which time a substantial amount of the desired penta-derivative was observed in the UVdetected HPLC chromatogram. The reaction was dried in vacuo and subsequently purified by HPLC (vide infra). Conversely, using (S)-MTPA-Cl, only a small fraction of $\mathbf{1}$ had been converted into the corresponding penta- $(R)$-MTPA derivative after 48 hours. At this time an additional $1.0 \mathrm{~mL}$ of anhydrous DCM and an additional $20 \mu \mathrm{g}$ of $(S)$-MTPA-Cl were added and the reaction was stirred at room temperature for an additional 5 days until a substantial amount of the desired penta-derivative was formed, as judged by the UV-detected HPLC chromatogram. At this point the reaction was quenched, dried in vacuo and the products subsequently purified by HPLC. Both arenicolide A penta-MTPA derivatives were purified by semi-prep HPLC [Luna $\mathrm{C}_{18}, 10 \times 250 \mathrm{~mm}$, flow rate $3.0 \mathrm{~mL} / \mathrm{min}$, ELSD detection; $50 \%$ $\mathrm{CH}_{3} \mathrm{CN}$ in $\mathrm{H}_{2} \mathrm{O}$ for 30 min then a linear gradient to $100 \% \mathrm{CH}_{3} \mathrm{CN}$ over 20 min then eluting with $100 \% \mathrm{CH}_{3} \mathrm{CN}$ for an additional $35 \mathrm{~min}$ ]. The purified penta-derivatives $(\mathbf{8})$ were dried under a stream of $\mathrm{N}_{2}(\mathrm{~g})$ and analyzed by $1 \mathrm{D}$ and $2 \mathrm{D}$ NMR.

\section{Arenicolide A Penta-( $R$ )-MTPA derivative $(\boldsymbol{R}-8,2.4 \mathrm{mg}, 29 \%$ yield)}

amorphous powder; $[\alpha]_{\mathrm{D}}+16.2(c 0.185, \mathrm{MeOH}) ; \mathrm{UV}(\mathrm{MeOH}) \lambda_{\max }(\log \varepsilon) 203$ (4.6), 234 (4.5), $262(4.1) \mathrm{nm}$; IR (NaCl) $v_{\max } 1754,1632,1451,1246,1172,1107,1017,722 \mathrm{~cm}^{-1}$; See Table S5 in supporting information for ${ }^{1} \mathrm{H}$ spectral data; ESIMS $\mathrm{m} / z$ $1907(\mathrm{M}+\mathrm{Na})^{+}$; HRESITOFMS $m / z$ 1907.6887 [calcd for $\mathrm{C}_{95} \mathrm{H}_{107} \mathrm{~F}_{15} \mathrm{O}_{22} \mathrm{Na}^{+}$, 1907.6906].

\section{Arenicolide A Penta-(S)-MTPA derivative (S-8, $2.3 \mathrm{mg}, 28 \%$ yield)}

amorphous powder; $[\alpha]_{D}-36.8$ (c 0.185, MeOH); UV (MeOH) $\lambda_{\max }(\log \varepsilon) 203$ (4.2), 234 (4.0), $262(3.7) \mathrm{nm}$; IR (NaCl) $v_{\max }$ 1745, 1246, 1164, 1131, $1017 \mathrm{~cm}^{-1}$; See Table S5 in supporting information for ${ }^{1} \mathrm{H}$ spectral data; ESIMS $\mathrm{m} / \mathrm{z} 1907(\mathrm{M}+\mathrm{Na})^{+}$; HRESITOFMS $\mathrm{m} / \mathrm{z}$ 1907.6903 [calcd for $\mathrm{C}_{95} \mathrm{H}_{107} \mathrm{~F}_{15} \mathrm{O}_{22} \mathrm{Na}^{+}$, 1907.6906].

\section{Supplementary Material}

Refer to Web version on PubMed Central for supplementary material.

\section{Acknowledgements}

This research is a result of financial support from the NIH, National Cancer Institute through grant CA44848. The $500 \mathrm{MHz}$ NMR spectrometer used in this research was funded by the NIH Shared Resources Program under grant S10RR017768. Additional financial support was provided by the University of California Industry-University Cooperative Research Program (IUCRP, grant BioSTAR 10354). PRJ and WF are scientific advisors to and stockholders in Nereus Pharmaceuticals, the corporate sponsor of the IUCRP award. The terms of this arrangement have been reviewed and approved by the University of California, San Diego in accordance with its conflict of interest policies. High-resolution mass spectral analyses were carried out by The Scripps Center for Mass Spectrometry or Nereus Pharmaceuticals. We thank Lisa Zeigler for the bioassay data, Chris Kauffman for assistance with the fermentation, and W. Yoshida (University of Hawaii at Manoa) and T. Bugni (University of Utah) for assistance with the G-BIRDR-HSQMBC experiment.

\section{References and Notes}

1. Verdine GL. Nature 1996;384s:11-13. [PubMed: 8895593]

2. Peláez F. Biochem Pharm 2006;71:981-990. [PubMed: 16290171]

3. Bulter MS. Nat Prod Rep 2005;22:162-195. [PubMed: 15806196]

4. Feling RH, Buchanan GO, Mincer TJ, Kauffman CA, Jensen PR, Fenical W. Angew Chem, Int Ed 2003;42:355-357. 
5. Oh DC, Williams PG, Kauffman CA, Jensen PJ, Fenical W. Org Lett 2006;8:1021-1024. [PubMed: 16524258]

6. Mincer TJ, Jensen PR, Kauffman CA, Fenical W. Appl Environ Microbiol 2002;68:5005-5011. [PubMed: 12324350]

7. For the isolation and structure elucidation of the other compound see Williams PG, Asolkar RN, Kondratyuk T, Pezzuto JM, Jensen PR, Fenical W. J Nat Prod. 2006Mancuscipt Accepted

8. As previously described, Salinispora arenicola strains also produce compounds belonging to the known staurosporine and rifamycin structural classes, see: Jensen PR, Mincer TJ, Williams PG, Fenical W. Antonie van Leeuwenhoek 2005;87:27-36.

9. For a report confirming the production of rifamycin from S. arenicola, see: Kim TK, Hewavitharana AK, Shaw PN, Fuerst JA. Appl Environ Microbiol 2006;72:2118-2125. [PubMed: 16517661]

10. It should be noted that it would not have been possible to confidently assign the structure of 1 solely based on the data recorded in $\mathrm{CDCl}_{3}$ due to spectral overlap.

11. Ratnayake AS, Hemscheidt T. Org Lett 2002;4:4667-4669. [PubMed: 12489956]

12. The corresponding macrocycle 5 , was identified via its molecular weight and the distinctive chromophore associated with the arenicolides [Supplemental S43, S44].

13. NMR solvents included MeOH- $d_{4}$, pyridine- $d_{5}, \mathrm{CH}_{3} \mathrm{CN}-d_{3}$, acetone- $d_{6}, \mathrm{CDCl}_{3}$, and DMSO- $d_{6}$.

14. Matsumori N, Kaneno D, Murata M, Nakamura H, Tachibana K. J Org Chem 1999;64:866-876. [PubMed: 11674159]

15. (a) Marquez BL, Gerwick WH, Williamson RT. Magn Reson Chem 2001;39:499-530. (b) Williamson RT, Marquez BL, Gerwick WH, Kover KE. Magn Reson Chem 2000;38:265-273.

16. Rychnovsky SD, Rogers B, Yang G. J Org Chem 1993;58:3511-3515.

17. See compound 33 in Tsuboi K, Ichikawa Y, Naganawa A, Isobe M, Ubukata M, Isono K. Tetrahedron 1997;53:5083-5102.

18. $\mathrm{In}_{\mathrm{CDCl}}$, the proton signals for $\mathrm{H}-31$ and $\mathrm{H}-32$ overlap.

19. Recent work has shown that the $\mathrm{J}_{\mathrm{CH}}$ value at centers directly adjacent to epoxides varies significantly from those in acyclic systems, see: Chevallier C, Bugni TS, Feng X, Harper MK, Orendt AM, Ireland CM. J Org Chem 2006;71:2510-2513. [PubMed: 16526806]

20. a) Westley JW, Evans RH, Harvey G, Pitcher RG, Pruess DL, Stempel A, Berger J. J Antibiot 1974;27:288-297. [PubMed: 4850784] b) Cane DE, Celmer WB, Westley JW. J Am Chem Soc 1983;105:3594-600.

21. Baldwin JE. J C S Chem Comm 1976;18:734-736.

22. Nicalaou KC, Prasad CVC, Somer PK, Hwang CK. J Am Chem Soc 1989; 111:5335-5340.

23. Valentine JC, McDonald FE, Neiwert WA, Hardcastle KI. J Am Chem Soc 2005;127:4586-4587. [PubMed: 15796519]

24. Janda KD, Shevlin CG, Lerner RA. Science 1993;259:490-493. [PubMed: 8424171]

25. Shimizu, Y. Natural Toxins" Animals, Plant and Microbial. Harris, JB., editor. Clarendon; Oxford: 1986. p. 123 (b) Nakanishi K. Toxicon 1985;23:473-479. [PubMed: 3895583]

26. For an interesting discussion of Balwin's rules in relation to polyether biosynthesis, see: Spencer JB, Gallimore AR. Angew Chem Int Ed 2006;45:4406-4413.

27. Payne GB. J Org Chem 1962;27:3819-3822.

28. Acetonide formation of 5 resulted in a complex mixture of products one of which appeared to contain the substituted THF ring with a methoxy group rather than a hydroxyl group at C-31. This new methoxy group likely originates from dimethoxypropane upon acetonide formation via an initial $\mathrm{S}_{\mathrm{N}} 2$ at C-31.

29. The paucity of distinct transannular NOE correlations, which prevented relating these stereochemical units has been previously noted. For an excellent example of this approach see Constantine, Keith L, Mueller L, Huang S, Abid S, Lam KS, Li W, Leet JE. J Am Chem Soc 2002;124:7284-7285. [PubMed: 12071733]

30. The one exception to this is for compound 2 where ozonolysis with oxidative workup would generate tartaric acid from $\mathrm{C}-5$ through $\mathrm{C}-7$ while a reductive workup would generate threitol. To date we have been unable to resolve the peracyl-derivatives of L- and D- threitol by chiral GC-MS. 
31. Exciton coupling circular dichroism (ECCD) of the 1,3-diol resulting from C-21 to C-26 was a possibility but required either the synthesis of the resulting degradation product for comparison or an accurate assessment of the conformational preferences of the degradation product. For precedent in using ECCD for 1,3-diols see Zhao N, Zhou P, Berova N, Nakanishi K. Chirality 1995;7:636-651. [PubMed: 8593257]

32. Traditionally, acyclic 1,5-diols, such as that derived from C-28 to C-36, are not amenable to stereochemical analysis by exciton coupling because their conformational flexibility results in a null $\mathrm{CD}$ signal due to signal averaging. For a elegant solution to this problem involving restricting the conformational flexibility the derivatized acyclic 1,n-diol using liposomes see (a) MacMillan JB, Molinski TF. J Am Chem Soc 2004;126:9944-9945. [PubMed: 15303868] (b) MacMillan JB, Linington RG, Andersen RJ, Molinski TF. Angew Chem, Int Ed 2004;43:5946-5951.

33. Attempts at the exhaustive degradation of 1 using cross-metathesis were unsuccessful under several conditions using both ethylene and styrene.

34. Attempts to crystallize 1 from a variety of solvents met with little success.

35. In a separate series of experiments, we attempted to prepare the tetra-MTPA derivatives of the acetonide protected methanolysis product of 1 (5). Unfortunately, we were not able to prepare an adequate amount of the $R$-MTPA derivative of this compound for NMR analysis.

36. Latypov SK, Seco JM, Quiñoá E, Riguera R. J Org Chem 1996;61:8569-8577.

37. Kwon HC, Kauffman CA, Jensen PR, Fenical W. J Am Chem Soc 2006;128:1622-1632. [PubMed: 16448135]

38. Comparing the ${ }^{3} J_{\mathrm{H}, \mathrm{H}}$ values for the MTPA derivatives with the parent compound 1 suggests both exist in similar conformations.

39. (a) Kobayashi J, Shimbo K, Sato M, Shiro M, Tsuda M. Org Lett 2000;2:2805-2807. [PubMed: 10964370] (b) Jansen R, Kunze B, Reichenbach H, Höfle G. Eur J Org Chem 2000;6:913-919. (c) Tsuda M, Endo T, Kobayashi J. Tetrahedron 1999;55:14565-14570. (d) Yamada K, Ueda K, Uemura D. Tetrahedron Lett 1999;40:6309-6312. (e) Tanahashi T, Takenaka Y, Nagakura N, Nishi T. J Nat Prod 1999;62:1311-1315. [PubMed: 10514322] (f) Harrigan GG, Luesch H, Yoshida WY, Moore RE, Nagle DG, Biggs J, Park PU, Paul V. J Nat Prod 1999;62:464-467. [PubMed: 10096859]

40. Freire F, Manuel J, Quiñoá E, Riguera R. J Org Chem 2005;70:3778-3790. [PubMed: 15876061]

41. For example for structure determination using a per-MTPA derivative see: Chávez D, Acevedo LA, Mata R. J Nat Prod 1998;61:419-412. For the structure revison see Takahashi S, Maeda K, Hirota S, Nakata T. Org, Lett 1999;1:2025-2028. [PubMed: 10905863]

42. Grubbs RH. Tetrahedron 2004;60:7117-7140.

43. Connon SJ, Blechert S. Angew Chem, Int Ed 2003;42:1900-1923.

44. Chatterjee AK, Choi TL, Sanders DP, Grubbs RH. J Am Chem Soc 2003;125:11360-11370. [PubMed: 16220959]

45. Olefin cross metathesis has been used to attached chromophores to natural products for circular dichroic exciton coupling. See (a) Tanaka K, Nakanishi K, Berova N. J Am Chem Soc 2003;125:10802-10803. [PubMed: 12952456] (b) Tanaka K, Itagaki Y, Satake M, Naoki H, Yasumoto T, Nakanishi K, Berova N. J Am Chem Soc 2005;127:9561-9570. [PubMed: 15984883] 

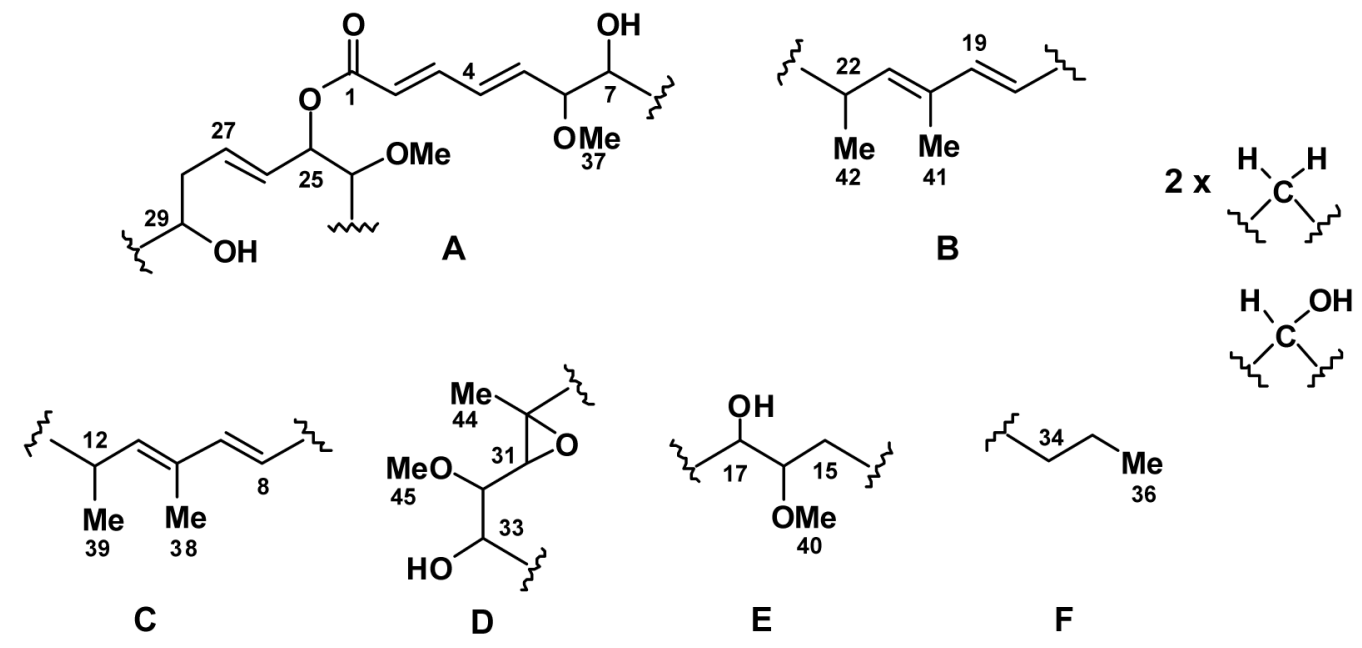

Figure 1.

Partial Structures Determined for $\mathbf{1}$ in Acetone- $d_{6}$ 


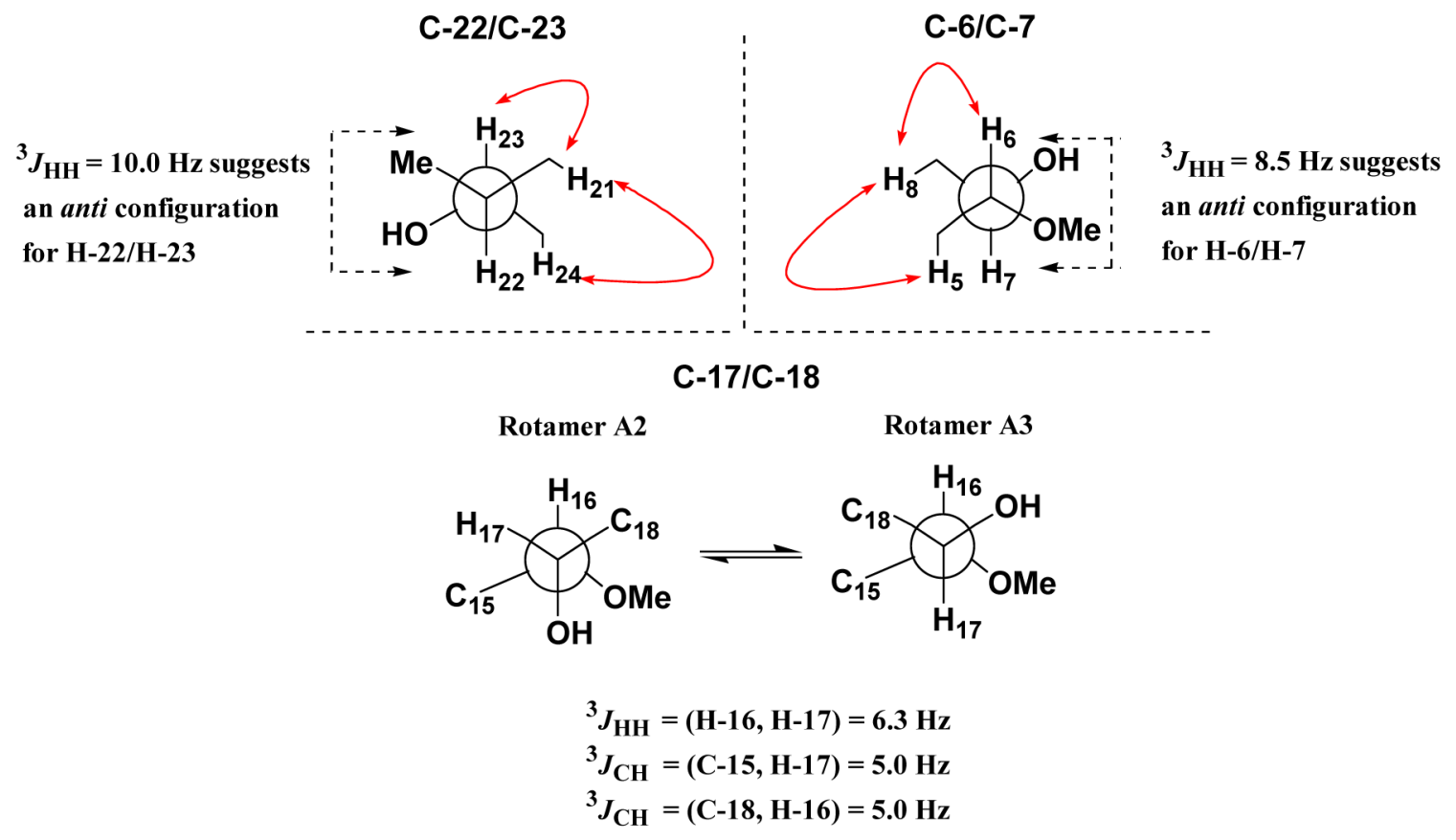

Figure 2.

NOE Correlations (Red) and ${ }^{3} J_{\mathrm{CH}}$ Values Used to Assign the Relative Configuration 

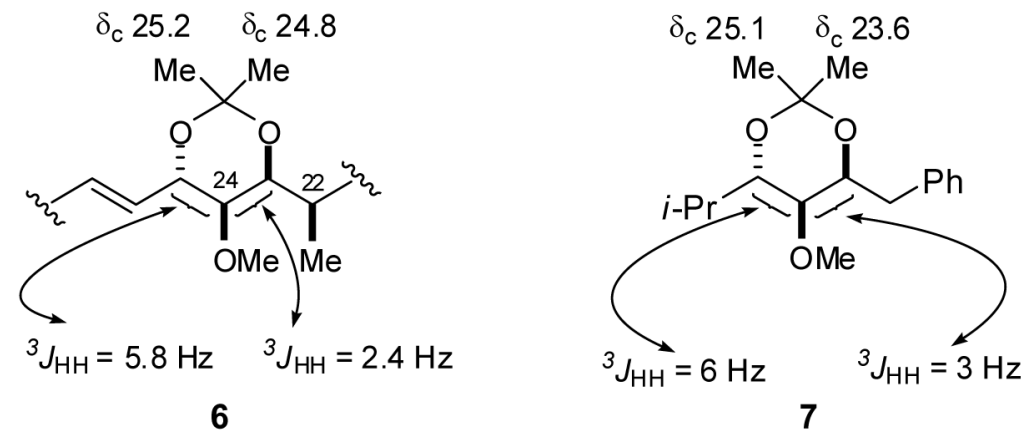

Figure 3.

Comparison of NMR Spectroscopic Data for the Acetonide Derivative of the Methanolysis Product of 1 (6) and the Model Compound 7. 


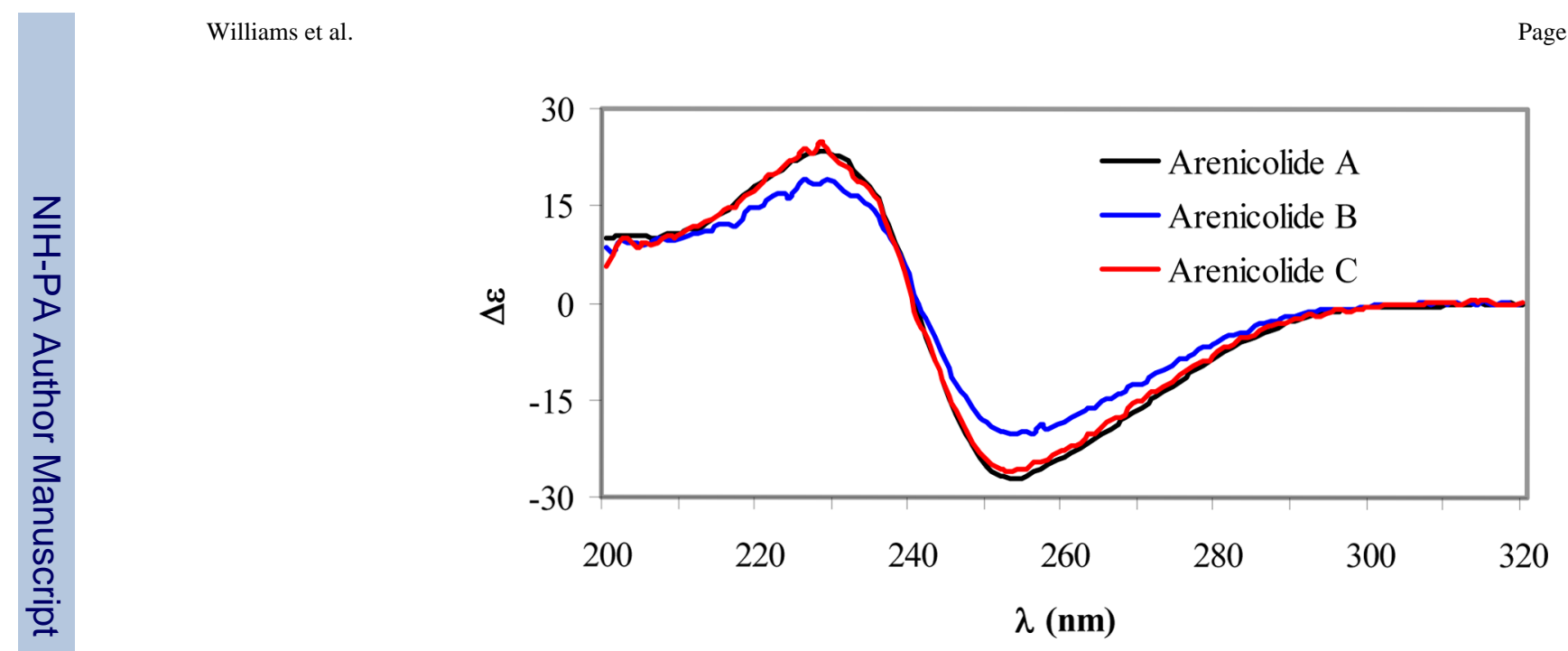

Figure 4.

CD Spectra of 1-3 in $\mathrm{MeOH}$. 

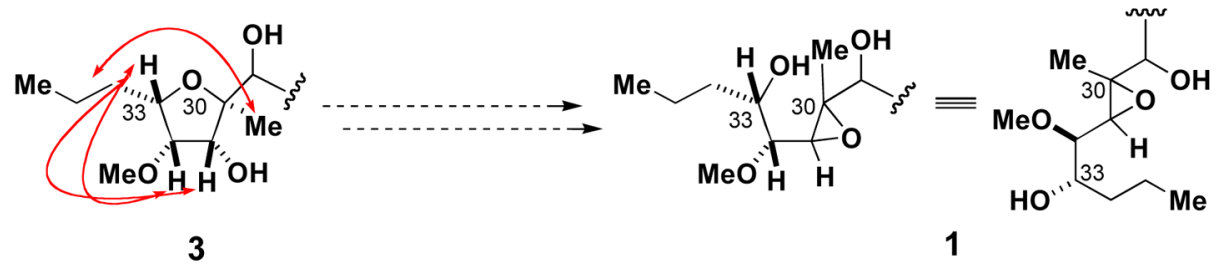

Figure 5.

Relative Configuration of the THF Ring based on NOE correlations. 

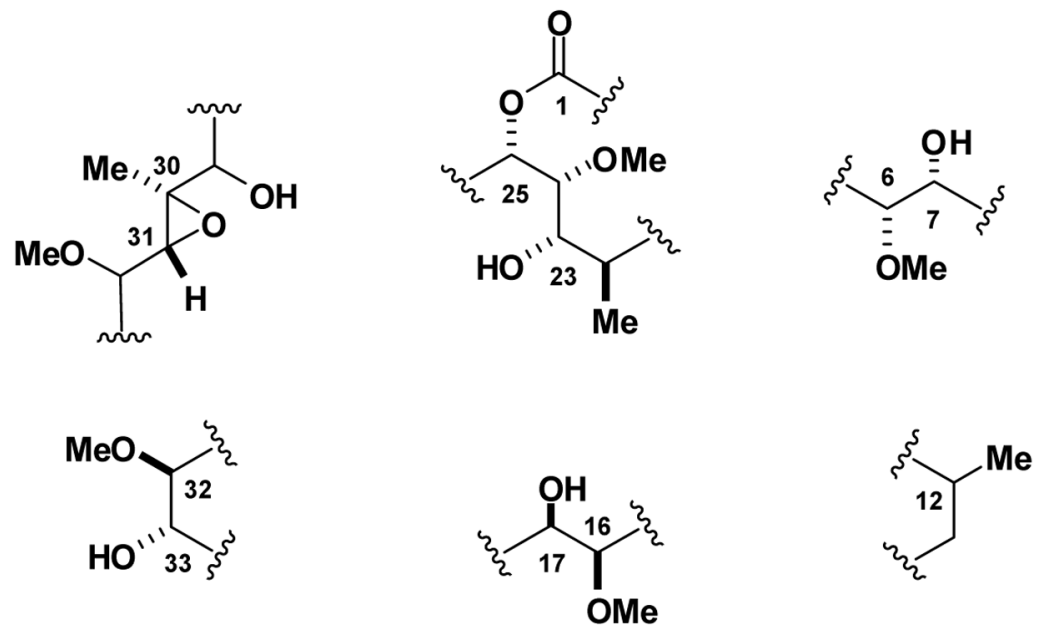

Figure 6.

Relative Stereochemical Assignments of the Isolated Units. 


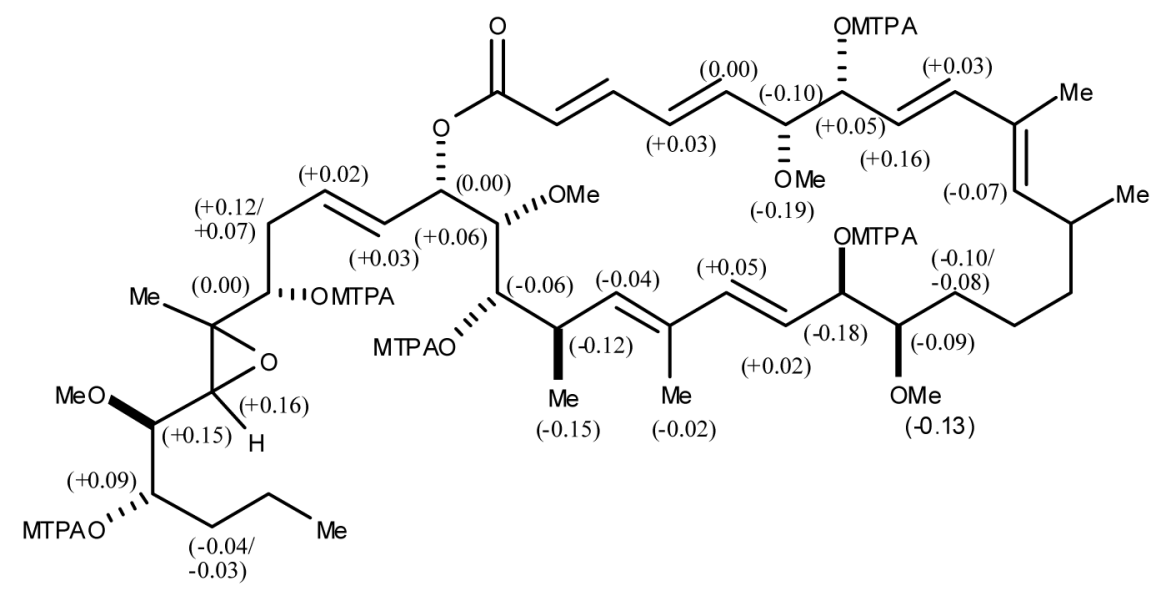

Figure 7.

$\Delta \delta_{S-R}$ Values for the Penta-MTPA Derivatives. 

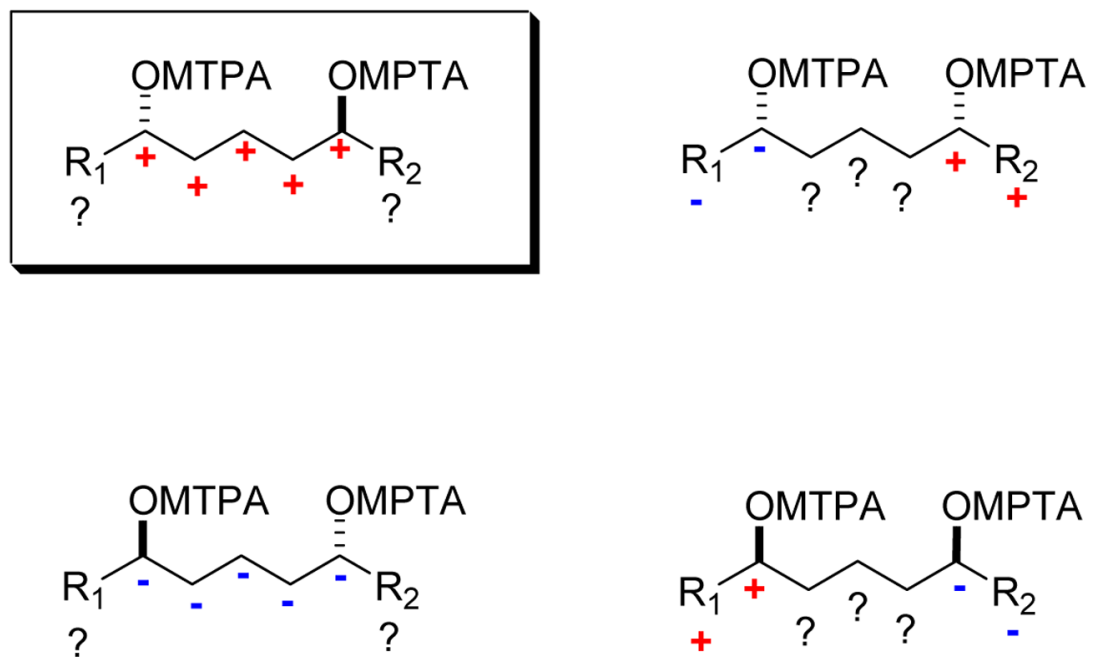

Figure 8.

Predictive $\Delta \delta_{S-R}\left(+\right.$ or - ) Patterns for bis-MTPA derivatives. ${ }^{40}$ Atoms labeled "?" are not used for that configurational assignment. 

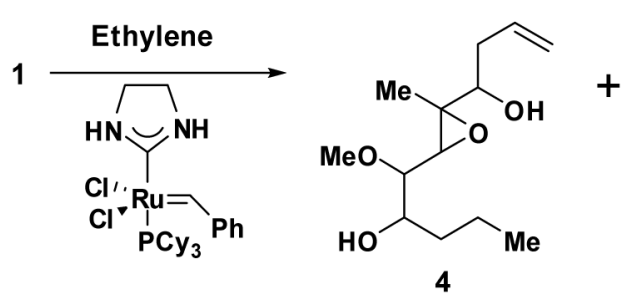

$[\mathrm{M}+\mathrm{Na}]^{+} \mathbf{2 6 7}$

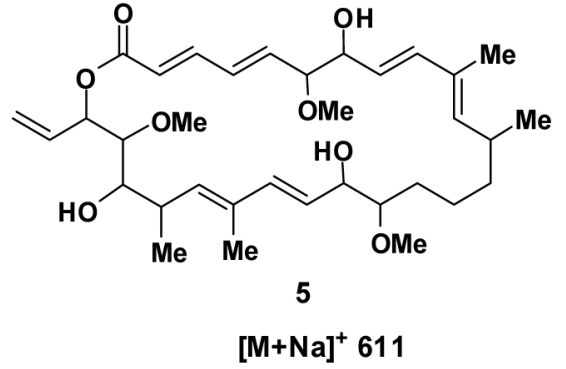

Scheme 1.

Olefin Cross-Metathesis Reaction of $\mathbf{1}$ 
Table 1

NMR spectroscopic data for 1 recorded in acetone- $d_{6}(500 \mathrm{MHz})$

\begin{tabular}{|c|c|c|c|c|}
\hline $\mathbf{C} / \mathbf{H} \#$ & $\delta_{\mathrm{C}}, \mathrm{CH} \#$ & $\delta_{\mathbf{H}}(J$ in $\mathbf{H z})$ & COSY & HMBC \\
\hline 1 & $166.0, \mathrm{C}$ & & & 2,3 \\
\hline 2 & $122.7, \mathrm{CH}$ & $5.96, \mathrm{~d}(14.9)$ & & 4 \\
\hline 3 & 144.6, CH & $7.23, \mathrm{dd}(14.9,11.2)$ & 2,4 & 4,5 \\
\hline 4 & 132.6, CH & 6.42 , dd $(15.4,11.2)$ & 3,5 & 2,6 \\
\hline 5 & $140.7, \mathrm{CH}$ & $5.91, \mathrm{dd}(15.4,8.0)$ & 6 & 3 \\
\hline 6 & $86.7, \mathrm{CH}$ & $3.57, \mathrm{~d}(8.0)$ & & $4,5,8,7,37$ \\
\hline 7 & $75.8, \mathrm{CH}$ & $3.96, \mathrm{~d}(8.3)$ & 8,6 & 5 \\
\hline 8 & $126.4, \mathrm{CH}$ & $5.35, \mathrm{dd}(15.6,8.3)$ & 7 & 6,7 \\
\hline 9 & $139.3, \mathrm{CH}$ & $6.14, \mathrm{~d}(15.6)$ & 8 & $7,11,38$ \\
\hline 10 & $132.3, \mathrm{C}$ & & & $8,9,38$ \\
\hline 11 & 140.6, CH & $5.23, \mathrm{~d}(9.8)$ & 12,38 & $9,38,39$ \\
\hline 12 & $33.2, \mathrm{CH}$ & $2.49, \mathrm{~m}$ & 13,39 & $11,13,39$ \\
\hline 13 & $38.2, \mathrm{CH}_{2}$ & $1.24, \mathrm{~m}$ & 12 & 39 \\
\hline $14 \mathrm{a}$ & $24.2, \mathrm{CH}_{2}$ & $1.39, \mathrm{~m}$ & & $12,15,16$ \\
\hline $14 \mathrm{~b}$ & & $1.24, \mathrm{~m}$ & & \\
\hline $15 \mathrm{a}$ & $31.2, \mathrm{CH}_{2}$ & $1.43, \mathrm{~m}$ & 16 & \\
\hline $15 \mathrm{~b}$ & & $1.29, \mathrm{~m}$ & & \\
\hline 16 & $85.6, \mathrm{CH}$ & $3.02, \mathrm{dt}(7.8,4.9)$ & 17 & $17,18,40$ \\
\hline 17 & 75.7, $\mathrm{CH}$ & $3.96, \mathrm{~m}$ & 18 & \\
\hline 18 & $129.5, \mathrm{CH}$ & $5.60, \mathrm{dd}(16.1,8.3)$ & 17 & \\
\hline 19 & $136.9, \mathrm{CH}$ & $6.16, \mathrm{~d}(16.1)$ & 18 & 21,41 \\
\hline 20 & $133.8, \mathrm{C}$ & & & $18,19,41$ \\
\hline 21 & $136.0, \mathrm{CH}$ & $5.27, \mathrm{~d}(10.3)$ & 22,41 & $19,41,42$ \\
\hline 22 & $38.0, \mathrm{CH}$ & $2.75, \mathrm{~m}$ & 23,42 & $22,24,42$ \\
\hline 23 & $76.5, \mathrm{CH}$ & $3.29, \mathrm{~m}$ & 29-OH, 28 & $22,24,42$ \\
\hline 24 & $83.4, \mathrm{CH}$ & $3.33, \mathrm{~m}$ & & 45 \\
\hline 25 & $78.5, \mathrm{CH}$ & $5.40, \mathrm{dd}(6.3,2.4)$ & 24 & 24,25 \\
\hline 26 & $128.9, \mathrm{CH}$ & $5.82, \mathrm{~m}$ & 25 & $24,25,28$ \\
\hline 27 & $132.0, \mathrm{CH}$ & $5.82, \mathrm{~m}$ & & 26,28 \\
\hline $28 \mathrm{a}$ & $37.5, \mathrm{CH}_{2}$ & 2.30, ddd $(16.1,5.4,3.4)$ & 27 & 27 \\
\hline $28 \mathrm{~b}$ & & 2.10, ddd $(16.1,9.3,6.8)$ & 27 & \\
\hline 29 & 76.7, $\mathrm{CH}$ & 3.18 , dd $(9.3,3.4)$ & $29-\mathrm{OH}, 28$ & $31,44,28$ \\
\hline 30 & 62.1, C & & & 31,44 \\
\hline 31 & $62.7, \mathrm{CH}$ & $2.85, \mathrm{~d}(8.3)$ & 32 & 44,32 \\
\hline 32 & $83.9, \mathrm{CH}$ & $2.98, \mathrm{dd}(8.3,5.9)$ & 33 & $33-\mathrm{OH}, 31$ \\
\hline 33 & $72.0, \mathrm{CH}$ & $3.56, \mathrm{~m}$ & 32,34 & 32,34 \\
\hline $34 \mathrm{a}$ & $36.1, \mathrm{CH}_{2}$ & $1.55, \mathrm{~m}$ & 33,35 & $32,36,35$ \\
\hline $34 \mathrm{~b}$ & & $1.42, \mathrm{~m}$ & 33,35 & \\
\hline $35 \mathrm{a}$ & $19.5, \mathrm{CH}_{2}$ & $1.53, \mathrm{~m}$ & 36 & \\
\hline $35 \mathrm{~b}$ & & $1.61, \mathrm{~m}$ & 36 & \\
\hline 36 & $14.4, \mathrm{CH}_{3}$ & $0.90, \mathrm{t}(7.3)$ & 35 & \\
\hline 37 & $57.0, \mathrm{CH}_{3}$ & $3.29, \mathrm{~s}$ & & 6 \\
\hline 38 & $12.9, \mathrm{CH}_{3}$ & $1.69, \mathrm{~d}(1.5)$ & & \\
\hline 39 & $20.8, \mathrm{CH}_{3}$ & $0.94, \mathrm{~d}(6.8)$ & 12 & 11 \\
\hline 40 & $58.9, \mathrm{CH}_{3}$ & $3.36, \mathrm{~s}$ & & 16 \\
\hline 41 & $13.0, \mathrm{CH}_{3}$ & $1.77, \mathrm{~d}(1.0)$ & & \\
\hline 42 & $17.8, \mathrm{CH}_{3}$ & $1.02, \mathrm{~d}(6.3)$ & & \\
\hline 43 & $60.5, \mathrm{CH}_{3}$ & $3.42, \mathrm{~s}$ & & 24 \\
\hline 44 & $13.7, \mathrm{CH}_{3}$ & $1.29, \mathrm{~s}$ & 22 & \\
\hline 45 & $58.5, \mathrm{CH}_{3}$ & $3.41, \mathrm{~s}$ & & 32 \\
\hline $29-\mathrm{OH}$ & & $3.83, \mathrm{~d}(3.9)$ & & \\
\hline
\end{tabular}


Table 2

NMR spectroscopic data for 1 recorded in $\mathrm{CDCl}_{3}(500 \mathrm{MHz})$.

\begin{tabular}{|c|c|c|c|c|}
\hline $\mathbf{C} / \mathbf{H} \#$ & $\delta_{\mathbf{C}}, \mathbf{C H \#}$ & $\delta_{H}(J$ in $\mathbf{H z})$ & COSY & HMBC \\
\hline 1 & $169.5, \mathrm{C}$ & & & $2,3,25$ \\
\hline 2 & $121.7, \mathrm{CH}$ & $5.89, \mathrm{~d}(16.0)$ & 3 & 3,4 \\
\hline 3 & $144.2, \mathrm{CH}$ & $7.24, \mathrm{dd}(16.0,11.2)$ & 2,4 & $2,4,5$ \\
\hline 4 & 132.6, CH & $6.25, \mathrm{dd}(15.0,11.2)$ & 3,5 & $2,3,6$ \\
\hline 5 & $139.2, \mathrm{CH}$ & $5.78, \mathrm{dd}(15.0,8.3)$ & 4,6 & 3 \\
\hline 6 & $85.6, \mathrm{CH}$ & $3.49, \mathrm{dd}(8.5,8.3)$ & 5,7 & $4,7,8,37$ \\
\hline 7 & $75.9, \mathrm{CH}$ & $3.98, \mathrm{bt}(8.5)$ & 6,8 & $4,6,9$ \\
\hline 8 & $123.0, \mathrm{CH}$ & $5.28, \mathrm{dd}(15.6,8.3)$ & 7,9 & $6,7,9$ \\
\hline 9 & $140.6, \mathrm{CH}$ & $6.10, \mathrm{~d}(15.6)$ & 8,11 & $6,7,8,38$ \\
\hline 10 & $130.4, \mathrm{C}$ & & & $7,8,9,38$ \\
\hline 11 & $141.4, \mathrm{CH}$ & $5.24, \mathrm{~d}(10.8)$ & $9,12,38$ & $9,38,39$ \\
\hline 12 & $32.8 \mathrm{CH}$ & $2.44, \mathrm{~m}$ & $11,13,39$ & 11,39 \\
\hline 13 & $37.5, \mathrm{CH}_{2}$ & $1.28, \mathrm{~m}$ & $12,14 \mathrm{ab}$ & $11,12,39$ \\
\hline $14 \mathrm{a}$ & $31.3, \mathrm{CH}_{2}$ & $1.52, \mathrm{~m}$ & $13,14 b, 15 a b$ & 16 \\
\hline $14 \mathrm{~b}$ & & $1.50, \mathrm{~m}$ & $13,14 \mathrm{a}, 15 \mathrm{ab}$ & 16 \\
\hline $15 \mathrm{a}$ & $23.9, \mathrm{CH}_{2}$ & $1.48, \mathrm{~m}$ & $14 \mathrm{ab}$ & 17 \\
\hline $15 \mathrm{~b}$ & & $1.26, \mathrm{~m}$ & $14 \mathrm{ab}$ & \\
\hline 16 & $84.6, \mathrm{CH}$ & $3.09, \mathrm{~m}$ & $14 a b, 15 b, 17$ & $17,18,40$ \\
\hline 17 & $76.0, \mathrm{CH}$ & $3.94, \mathrm{dd}(8.8,6.3)$ & 16,18 & 19 \\
\hline 18 & $127.0, \mathrm{CH}$ & $5.52, \mathrm{dd}(15.6,8.8)$ & 17,19 & 17 \\
\hline 19 & $138.2, \mathrm{CH}$ & $6.19, \mathrm{~d}(15.6)$ & 18 & 17,41 \\
\hline 20 & $133.4, \mathrm{C}$ & & & $18,19,22,41,42$ \\
\hline 21 & $135.3, \mathrm{CH}$ & 5.15, bd $(10.0)$ & 22,41 & $18,19,22,23,42$ \\
\hline 22 & $37.9, \mathrm{CH}$ & $2.65, \operatorname{tp}(10.0,6.5)$ & $21,23,42$ & $21,23,24,42$ \\
\hline 23 & $75.7, \mathrm{CH}$ & 3.17, bd $(10.0)$ & 22,24 & $21,22,24$ \\
\hline 24 & $81.4, \mathrm{CH}$ & 3.36, bd $(2.2)$ & 23,25 & 43 \\
\hline 25 & $78.9, \mathrm{CH}$ & $5.33, \mathrm{dt}(5.9,2.2)$ & 24,26 & $23,24,26,27$ \\
\hline 26 & $131.8, \mathrm{CH}$ & $5.80, \mathrm{~m}$ & 25 & $25,28,29$ \\
\hline 27 & $128.8, \mathrm{CH}$ & $5.80, \mathrm{~m}$ & $25,26,28 \mathrm{ab}$ & $24,25,28$ \\
\hline $28 \mathrm{a}$ & $36.3, \mathrm{CH}_{2}$ & $2.39, \mathrm{~m}$ & $27,28 b, 29$ & $25,26,27$ \\
\hline $28 \mathrm{~b}$ & & $2.13, \mathrm{~m}$ & $27,28 \mathrm{a}, 29$ & \\
\hline 29 & $74.1, \mathrm{CH}$ & $3.39, \mathrm{dd}(11.0,2.5)$ & $28 \mathrm{ab}$ & 28,44 \\
\hline 30 & $60.7, \mathrm{C}$ & & & $29,32,33,44$ \\
\hline 31 & $60.9, \mathrm{CH}$ & $3.04, \mathrm{~s}$ & 32 & $29,32,33,44$ \\
\hline 32 & $82.5, \mathrm{CH}$ & $3.07, \mathrm{~d}(3.9)$ & 31,33 & 45 \\
\hline 33 & $71.4, \mathrm{CH}$ & $3.68, \mathrm{dt}(8.3,3.9)$ & 32,34 & 34,35 \\
\hline 34 & $34.5, \mathrm{CH}_{2}$ & $1.46, \mathrm{~m}$ & $33,35 \mathrm{ab}$ & 35,36 \\
\hline $35 \mathrm{a}$ & $19.0, \mathrm{CH}_{2}$ & $1.58, \mathrm{~m}$ & $34,35 b, 36$ & \\
\hline $35 \mathrm{~b}$ & & $1.38, \mathrm{~m}$ & $34,35 \mathrm{a}, 36$ & 36 \\
\hline 36 & $14.0, \mathrm{CH}_{3}$ & $0.94, \mathrm{t}(7.0)$ & $35 a b$ & \\
\hline 37 & $56.8, \mathrm{CH}_{3}$ & $3.33, \mathrm{~s}$ & & 6 \\
\hline 38 & $12.5, \mathrm{CH}_{3}$ & $1.68, \mathrm{~s}$ & 11 & 9,11 \\
\hline 39 & $19.9, \mathrm{CH}_{3}$ & $0.95, \mathrm{~d}(7.0)$ & 12 & 11,12 \\
\hline 40 & $58.9, \mathrm{CH}_{3}$ & $3.47, \mathrm{~s}$ & & \\
\hline 41 & $12.7, \mathrm{CH}_{3}$ & $1.76, \mathrm{~s}$ & 21 & 19,21 \\
\hline 42 & $17.4, \mathrm{CH}_{3}$ & $1.02, \mathrm{~d}(6.5)$ & 22 & $21,22,23$ \\
\hline 43 & $60.8, \mathrm{CH}_{3}$ & $3.52, \mathrm{~s}$ & & 24 \\
\hline 44 & $14.1, \mathrm{CH}_{3}$ & $1.34, \mathrm{~s}$ & & \\
\hline 45 & $58.4, \mathrm{CH}_{3}$ & $3.51, \mathrm{~s}$ & & \\
\hline
\end{tabular}




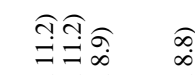

की

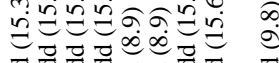

$\Xi \Xi \Xi \Xi \Xi$

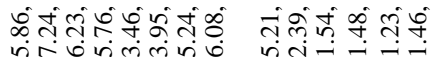

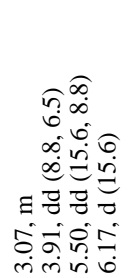

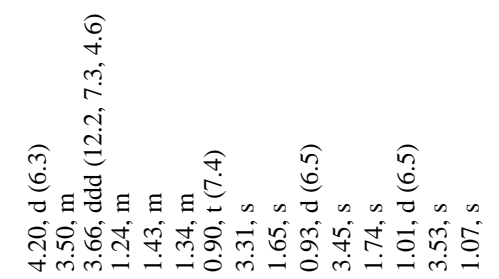

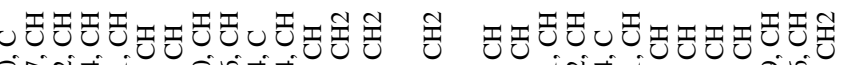

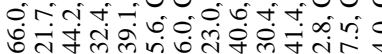

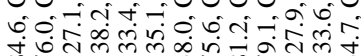

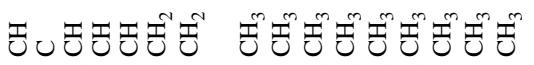

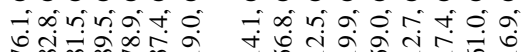

ণิণิำ

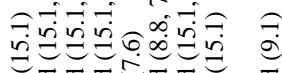

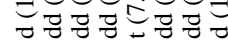

ம்

䆑

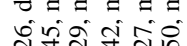

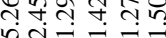

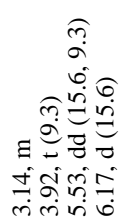

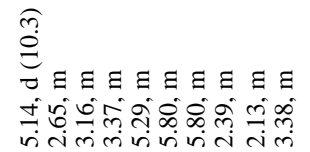

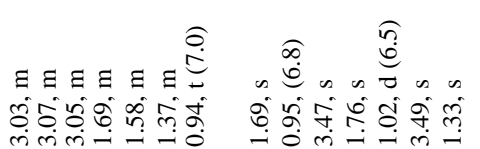

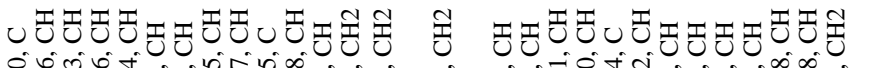

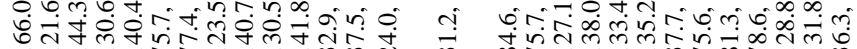

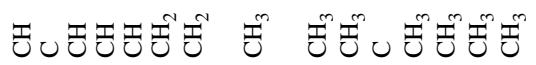

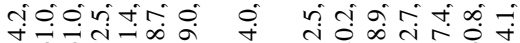

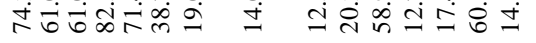

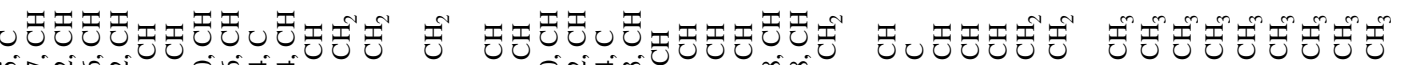

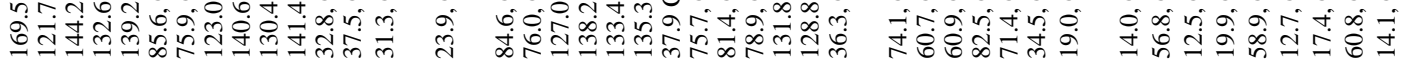




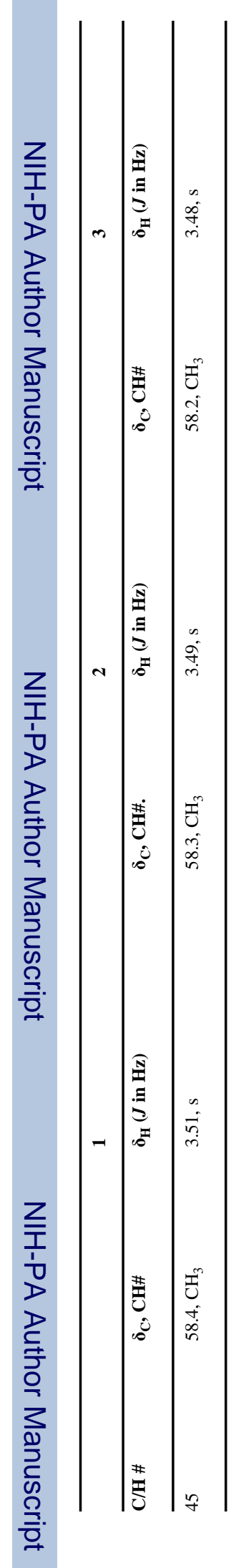

